\title{
Embryo and larval biology of the deep-sea octocoral Dentomuricea aff. meteor under different temperature regimes
}

\author{
Maria Rakka ${ }^{\text {Corresp., 1, } 2}$, António Godinho ${ }^{1,2}$, Covadonga Orejas ${ }^{3}$, Marina Carreiro-Silva ${ }^{1,2}$ \\ 1 IMAR-Instituto do Mar, Universidade dos Açores, Horta, Portugal \\ 2 Okeanos-Instituto de Investigação em Ciências do Mar da Universidade dos Açores, Horta, Portugal \\ 3 Centro Oceanográfico de Gijón, Instituto Español de Oceanografia, Gijón, Spain \\ Corresponding Author: Maria Rakka \\ Email address: marianinha.rk@gmail.com
}

Deep-sea octocorals are common habitat-formers in deep-sea ecosystems, however, our knowledge on their early life history stages is extremely limited. The present study focuses on the early life history of the species Dentomuricea aff. meteor, a common deep-sea octocoral in the Azores. The objective was to describe the embryo and larval biology of the target species under two temperature regimes, corresponding to the minimum and maximum temperatures in its natural environment during the spawning season. At temperature of $13 \pm 0.5^{\circ} \mathrm{C}$, embryos of the species reached the planula stage after $96 \mathrm{~h}$ and displayed a median survival of 11 days. Planulae displayed swimming only after stimulation, swimming speed was $0.24 \pm 0.16 \mathrm{~mm} \mathrm{~s}^{-1}$ and increased slightly but significantly with time. Under a higher temperature $\left(15^{\circ} \mathrm{C} \pm 0.5^{\circ} \mathrm{C}\right)$ embryos reached the planula stage $24 \mathrm{~h}$ earlier (after $72 \mathrm{~h}$ ), displayed a median survival of 16 days and had significantly higher swimming speed $\left(0.3 \pm 0.27 \mathrm{~mm} \mathrm{~s}^{-1}\right)$. Although the differences in survival were not statistically significant, our results highlight how small changes in temperature can affect embryo and larval characteristics with potential cascading effects in larval dispersal and success. In both temperatures, settlement rates were low and metamorphosis occurred even without settlement. Such information is rarely available for deep-sea corals, although essential to achieve a better understanding of dispersal, connectivity and biogeographical patterns of benthic species. 

different temperature regimes

$6{ }^{1}$ IMAR - Instituto do Mar, Universidade dos Açores, Rua Frederico Machado 4, 9901-862

7 Horta, Portugal

$8 \quad{ }^{2}$ OKEANOS-Instituto de Investigação em Ciências do Mar da Universidade dos Açores, 9901-

9 862, Horta, Portugal

$10{ }^{3}$ Centro Oceanográfico de Gijón, Instituto Español de Oceanografia (IEO), Calle de Ramón

11 González Fernández, 70B, 33212 Gijón

12

13 Corresponding Author:

14 Maria Rakka 1,2

15 Rua Frederico Machado 4, 9901-862 Horta, Portugal

16 Email address: marianinha.rk@gmail.com

17 


\section{Abstract}

19

Deep-sea octocorals are common habitat-formers in deep-sea ecosystems, however, our knowledge on their early life history stages is extremely limited. The present study focuses on the early life history of the species Dentomuricea aff. meteor, a common deep-sea octocoral in the Azores. The objective was to describe the embryo and larval biology of the target species under two temperature regimes, corresponding to the minimum and maximum temperatures in its natural environment during the spawning season. At temperature of $13 \pm 0.5^{\circ} \mathrm{C}$, embryos of the species reached the planula stage after $96 \mathrm{~h}$ and displayed a median survival of 11 days. Planulae displayed swimming only after stimulation, swimming speed was $0.24 \pm 0.16 \mathrm{~mm} \mathrm{~s}^{-1}$ and increased slightly but significantly with time. Under a higher temperature $\left(15^{\circ} \mathrm{C} \pm 0.5^{\circ} \mathrm{C}\right)$ embryos reached the planula stage $24 \mathrm{~h}$ earlier (after $72 \mathrm{~h}$ ), displayed a median survival of 16 days and had significantly higher swimming speed $\left(0.3 \pm 0.27 \mathrm{~mm} \mathrm{~s}^{-1}\right)$. Although the differences in survival were not statistically significant, our results highlight how small changes in temperature can affect embryo and larval characteristics with potential cascading effects in larval dispersal and success. In both temperatures, settlement rates were low and metamorphosis occurred even without settlement. Such information is rarely available for deep-sea corals, although essential to achieve a better understanding of dispersal, connectivity and biogeographical patterns of benthic species.

\section{Introduction}

Species persistence requires the successful completion of a life cycle against biotic and abiotic odds, in most cases starting with survival at early life history stages. For benthic marine invertebrates, larval stages constitute the only pelagic phase that ensures dispersal and 
40 connectivity among populations (Cowen and Sponaugle, 2009). Moreover, early life events such

41 as larval survival and settlement determine the fate of the sessile, adult phase and are extremely

42 important (Marshall and Morgan, 2011; Byrne, 2012). In deep-sea communities, which are

43 dominated by benthic marine invertebrates, knowledge on early life stages is therefore key in

44 understanding species distributions, biogeographical patterns and metapopulation dynamics

45 (Treml et al., 2015), constituting an essential tool for management (Hilario et al., 2015).

Deep-sea octocorals are major habitat-formers in the deep-sea, usually occurring in complex geological settings such as continental shelves and margins (Yesson et al., 2008, Taylor et al., 2013), underwater canyons (Brooke et al., 2017) and seamounts (Tempera et al., 2012; BragaHenriques et al., 2013). Due to the habitat requirements of some octocoral species, including hard substrates for settlement and strong currents which optimize food delivery, their distribution can be quite patchy (Bryan and Metaxas, 2006; Tong et al., 2012), as observed for other deep-sea benthic species (Miller and Gulasekera, 2017). Anthropogenic disturbance and global climate change are likely to cause habitat fragmentation by altering its characteristics (Sweetman et al., 2017; Levin et al., 2019) and causing a decrease in the available suitable habitat of some species (Morato et al., 2020). Under these circumstances, obtaining a solid understanding of larval biology and population connectivity is essential to understand community dynamics and the potential of deep-sea octocoral populations to recover from disturbance (Cowen et al., 2007;

58 Levin et al., 2020).

So far, our knowledge on larval biology of deep-sea octocorals is limited to a few brooding species (Cordes et al., 2001; Sun et al., 2010; 2011; Mercier and Hamel, 2011). In most of these cases, larvae displayed short competency periods with limited swimming behaviour (Sun et al., 2010), settlement within 2-5 days after release and rapid metamorphosis into primary polyps 
63 (Cordes et al., 2001; Sun et al., 2011). However, many deep-sea octocorals are broadcast-

64 spawners and are therefore expected to display different larval characteristics and dispersal

65 capabilities (Harrison and Wallace, 1990; Nishikawa et al., 2003). To our knowledge, up to date there is no detailed description of embryo and larval development of broadcast spawning deepsea octocorals. Larvae from broadcast spawning species undergo early development in the water column, where they are mostly transported as passive particles until they reach the planula stage. During transportation, embryos can be exposed to variable environmental conditions which may affect their development (Melzner et al., 2009). This phenomenon can be even more pronounced in larvae of deep-sea species, which often display upward swimming, crossing water masses with very different physicochemical characteristics (Young et al., 1996, 2012; Arellano et al., 2014; Stromberg and Larsson, 2017). In the case of deep-sea corals, the effect of natural fluctuations of environmental conditions, such as salinity and temperature, have only been addressed in the scleractinian Lophelia pertusa (Stromberg and Larsson, 2017).

The aim of this study was to provide a detailed description of the early life history traits of the deep-sea broadcast spawning species Dentomuricea aff. meteor, a common habitat-forming, deep-sea octocoral in the Azores. More specifically, the objectives were (1) to describe the embryo and larval development, larval survival, swimming and settlement behaviour of the target species and (2) to determine the effect of natural temperature variability on its embryo and larval traits. To achieve these objectives, we employed an experimental approach with assisted fertilization and larvae rearing in aquaria under two temperature regimes $\left(13 \pm 0.5^{\circ} \mathrm{C}\right.$ and $15 \pm$ $0.5^{\circ} \mathrm{C}$ ), representing the minimum and maximum temperatures experienced by the species in its natural habitat.

\section{Materials and Methods}


86 Target species and colony collection

87 The Azores Archipelago, located above the Mid-Atlantic Ridge, is a biodiversity hotspot for

88 deep-sea octocorals (Sampaio et al., 2019). Coral gardens (OSPAR, 2010) formed by deep-sea

89 octocorals are among the most prominent deep-sea communities on regional seamounts and

90 island slopes (Braga-Henriques et al., 2013). Dentomuricea aff. meteor is an octocoral species of

91 the family Plexauridae, so far only recorded on the seamounts of the North Mid-Atlantic Ridge.

92 It is common in regional seamounts between 200-600 meters (Braga-Henriques et al., 2013),

93 where it forms dense populations, often in combination with other octocoral species such as

94 Viminella flagellum and Callogorgia verticillata. The species is gonochoristic and presents

95 gametes all year round, with seasonal peaks of gamete maturation and spawning usually

96 occurring in autumn (Rakka et al., unpubl. data).

97 A total of 11 colonies of the species Dentomuricea aff. meteor were collected as by-catch from

98 experimental long-line fisheries on board RV Archipelago (ARQDAÇO monitoring programme).

99 Collection was performed at the summit of Condor Seamount, between 200-280 meters, in

100 September and October 2019. Colonies were divided in large fragments (20-30 cm height) and

101 were kept at the DeepSeaLab aquaria facilities (Orejas et al., 2019), in six 33L aquaria positioned

102 in a thermo-regulated room at $14^{\circ} \mathrm{C}$. Aquaria were supplied continuously with seawater (SW)

103 pumped from 5m depth, previously treated with UV light (P10 UVsystem \& Vecton 600

$104 \mathrm{TMC}^{\mathrm{TM}}$ ) and passed through $50 \mu \mathrm{m}$ and $1 \mu \mathrm{m}$ mesh filters. Circulation within the aquaria was

105 maintained by pumps. Seawater temperature was kept between $13-14^{\circ} \mathrm{C}$ with the aid of chillers

106 and salinity was $35.8 \pm 0.1$, similar to the natural conditions at the collection site (Santos et al.,

107 2013). Colonies were fed twice per day with a mixture of frozen zooplankton and microplankton 
108 which was frequently enriched with live microalgae (Chaetoceros calcitrans and

109 Nannochloropsis gaditana) and live rotifers.

110 Larval rearing

111 Larvae were obtained by maintaining reproductively active female and male colonies in the same

112 aquaria to achieve natural spawning and fertilization. Coral fragments were allowed to

113 acclimatize in the above aquaria conditions for approximately one month. Subsequently, colonies

114 with mature gametes were identified by dissecting two branchlets $(3-5 \mathrm{~cm}$ height $)$ from each

115 colony and observing their tissue under a dissecting microscope. Reproductively immature

116 colonies and fragments in poor condition were excluded from further analysis. This procedure

117 resulted in selection of six female and three male colonies. Coral fragments from the female

118 colonies were distributed in two aquaria, referred to as spawning aquaria. Subsequently the

119 fertile male colony with the higher number of available fragments was selected and four of its

120 fragments were distributed in each of the two spawning aquaria. The remaining male colonies

121 were not used to avoid polyspermy (Levitan et al., 2007).

122 To increase the potential of spawning, we enriched the aquaria water with free mature sperm,

123 obtained from the selected male colony. This was achieved by dissecting mature spermatocysts

124 from coral tissue, which were subsequently concentrated in $50 \mathrm{ml}$ flasks with filtered (mesh size:

$1250.2 \mu \mathrm{m}) \mathrm{SW}$, mixed by gently shaking and redistributed to the aquaria. Water inflow was paused

126 and aquaria pumps were substituted with aeration to ensure water circulation without losing or

127 harming potentially spawned gametes. Upon gamete release, which happened in batches

128 separated by intervals of at least 2-3 hours, gametes/fertilized eggs from each batch were

129 collected from the water column to a 750 ml-culture flask (20-100 fertilized eggs per flask), 
130 filled with filtered SW from the aquaria facilities (mesh size: $0.2 \mu \mathrm{m}$ ). Whenever more than 100

131 gametes/embryos were released in one batch, these were equally distributed to two flasks to

132 avoid maintaining larvae in high densities. During the first four days of the study we collected a

133 total of 688 gametes which were distributed to 7 batches. Three of these batches were large

134 enough to be split to two flasks (total $n=10$ flasks).

135 Temperature experiments

136 In order to choose appropriate temperature regimes for larval rearing, we utilized temperature

137 data collected during annual CTD surveys, under the framework of the projects CONDOR (EEA

138 Grants PT-0040) and SMaRT (SRECC- Azores Regional Government M.2.1.2/029/2011). Data

139 were collected between 2010 and 2012, above the coral garden where specimen collection took

140 place. Subsequently, we utilized the minimum and maximum recorded values during the

141 spawning season of the target species (October-November) to define the target rearing

142 temperatures $\left(13 \pm 0.5^{\circ} \mathrm{C}\right.$ and $\left.15 \pm 0.5^{\circ} \mathrm{C}\right)$. Two water baths were set-up, each maintaining

143 temperature within $\pm 0.5^{\circ} \mathrm{C}$ of the corresponding target temperature, with the aid of an aquaria

144 chiller and a heater, respectively. Each day, the collected batches were divided between the two

145 temperature treatments: immediately after collection of the released fertilized eggs/embryos,

146 culture flasks were randomly assigned to one of the two water baths ( $\mathrm{n}=5$ in each water bath).

147 This corresponded to a total of 346 and 342 embryos reared at $13^{\circ} \mathrm{C}$ and $15^{\circ} \mathrm{C}$ respectively.

148 Culture flasks were equipped with glass pipettes connected to an aquaria air pump, achieving

149 continuous light circulation, while the full volume of water in the flasks was exchanged daily.

150 Embryonic and larval development 
151 Embryos were monitored every 3-4 hours during the first 48 hours and subsequently once a day

152 until reaching the planula stage, to study their early development. In every monitoring event, all

153 embryos were counted to estimate survival. Additionally, 10-15 embryos were randomly

154 removed from each flask and photographed, with a digital camera (DIGICAM 5MEG LCMOS

155 MAC) attached to a microscope (10x), to record their developmental stage and size. Embryos

156 were subsequently returned to the flasks. Due to the sometimes prolonged gamete release,

157 gametes of the same batch were occasionally in slightly different developmental stages, therefore

158 the timing of embryonic development is approximate. Moreover, since it was not possible to

159 define the moment of fertilization, embryo development is presented in respect to the time of

160 gamete release. To estimate size, we measured width and length ( $\mathrm{mm}$ ) of embryos and larvae

161 (days 4 and 14) using the open software Fiji/Image J (Schindelin et al., 2012). The data were

162 subsequently used to estimate volume $\left(\mathrm{mm}^{3}\right)$ assuming larvae had the shape of a prolate spheroid

163 (Larsson et al., 2014). The ratio of length to width (LW ratio) was used as a proxy of sphericity.

164 Embryo and larval survival

165 After reaching the planula stage, larvae were counted every 2-3 days. The last count

166 corresponded to day 34,36 or 39 , depending on the batch. The obtained data were joined to the

167 dataset collected during embryo development to estimate larval survival during the whole

168 experimental period. Survival analysis was performed using the Kaplan-Meier method (Kaplan

169 and Meier, 1958), following the rationale of Graham et al. (2008). Since monitoring was done in

170 time intervals and the exact time of death for each larva was not known (interval-censored data),

171 we assumed that time of death was the moment at which each larva was observed for the last

172 time. The remaining larvae at the last monitoring event were considered alive (censored data). As

173 the Kaplan-Meier method does not allow for incorporation of replicate information into the 
174 analysis, we performed the analysis by pooling data from all batches together, for each rearing

175 temperature. Subsequently the analysis was repeated separately for each batch, to provide

176 information about the variability among batches (Graham et al., 2008). A log-rank test was

177 performed to compare the survival curves between larvae reared under $13^{\circ} \mathrm{C}$ and $15^{\circ} \mathrm{C}$. Survival

178 analysis was performed by using the packages survival (Therneau and Grambsch, 2017) and

179 survminer (Kassambara et al., 2019) in R 3.5.0 (R Core Team, 2018).

\section{Larval swimming behaviour}

182

183

184

185

186

187

188

189

190

191

192

193

194

195

Data on swimming speed and behaviour were collected by video recording and analysis. Videos were recorded with a Canon EOS 600D digital camera, equipped with a regular 22-55mm lens, on day 4 and day 15 after spawning, which corresponded to the first day larvae reached the mature planula stage and the second day larvae started settling, respectively. To minimize larval handling, swimming behaviour was recorded in the same culture flasks used for larval rearing. Videos were captured in the dark, using lateral led lights for illumination (Stromberg and Larsson, 2017). Flasks were positioned in front of a black slide with a calibrated grid that was used as background and a 2-minute waiting period was implemented to ensure no water movement was interfering with larval swimming. Subsequently, three videos (duration: $1 \mathrm{~min})$ were recorded at three minute intervals.

Videos were converted to frames and were analyzed by an automatic particle tracking method, using the open software Fiji/Image J (Schindelin et al., 2012) and the plugin TrackMate (Tinevez et al., 2017) to record data on vertical swimming behaviour, namely swimming direction (up/down), displacement and swimming speed. Estimates of swimming speed only considered 
196 tracks with displacement higher than $2 \mathrm{~mm}$, to exclude data from larvae that did not move or

197 moved minimally.

198 Pelagic phase and larval settlement

199 During the counts performed for survival, each larva was assigned to one of four stages: planula,

200 settled, pelagically metamorphosed and deformed. Because counts were made simultaneously for

201 all flasks and each flask contained a batch of different age, e.g. some batches were released with

202 1-3 day difference, when average counts were estimated these were sometimes heavily

203 influenced by the available count for that day. To be able to estimate robust mean counts for each

204 monitoring day, missing counts were regenerated for each batch separately by using linear

205 interpolation between existing data points (Dong and Peng, 2013), by using the R package VIM

206 (Kowarik and Templ, 2016). Extrapolation was performed only until the last datapoint that was

207 available for each batch, i.e. there was no attempt to predict the trend past the last available

208 count. Subsequently, counts of each stage were divided by the total number of living larvae in

209 each batch. This resulted in estimates of the proportion of the surviving larvae in each stage and

210 was used to analyze the behaviour of the remaining larvae. Lastly, on days 4 and 14 after

211 spawning, five planulae were removed from each flask (total $n=25$ for each temperature regime)

212 and photographed with a digital microscope camera to estimate their size.

213 Since larvae did not display clear bottom probing behaviour, the onset of competency was

214 defined by settlement or pelagic metamorphosis. After the first larval settlement (day 14),

215 substrate was provided to the culture flasks in order to monitor settlement behaviour. Three

216 flasks from each temperature regime were randomly selected and three pieces (approximate

217 diameter: $5 \mathrm{~mm})$ of basalt rock attached to a plastic slide $(10 \mathrm{~mm} \times 80 \mathrm{~mm})$ were offered as 
218 potential substrate in each flask. Basalt was selected because it is an abundant hard substrate in

219 the deep seafloor of the Azores and where the studied species is frequently observed. The

220 substrate was not pretreated to develop biofilm. Settled larvae were observed and photographed

221 every 2-3 days to assess and describe settlement and metamorphosis, during a period of

222 approximately two weeks. After metamorphosis was observed, a mixture of live microalgae

223 (Nannochloropsis gaditana and Chaetoceros calcitrans) and rotifers was provided weekly as a

224 potential food source.

226 Statistical analysis

227 For all the dependent variables in question, we firstly performed exploratory analysis (Zuur et

228 al., 2010) to select the most appropriate modeling method. The effect of each independent

229 variable was subsequently tested with linear models (LMs), by adding the independent variables

230 progressively to the respective model and using maximum likelihood ratio (MLR) tests and the

231 Akaike Information Criterion (AIC). Data collected from monitoring larvae stages (proportions)

232 were modeled by means of Generalized Additive Models (GAMs) with a binomial distribution.

233 Summarized results of the MLR test for each variable in question are provided in Table 1, while

234 the results from each selected model are provided graphically as supplementary material (Fig.

235 S1-S5). Statistical analysis was performed in R (R Core Team, 2019).

\section{Results}

237 Spawning 
238 Gamete release occurred for the first time on the $27^{\text {th }}$ of November, one day after the new moon.

239 Oocytes were encountered 15 minutes after enrichment with free live sperm, in both aquaria.

240 Spawning was not synchronized among colonies, neither among polyps of the same colony.

241 Despite careful observation, it was not possible to directly observe polyps releasing sperm or

242 oocytes and determine whether one or more colonies participated in gamete release. Similarly, it

243 was not possible to directly observe if fertilization was internal or external. All collected oocytes

244 were fertilized, therefore fertilization was either internal, or external with very high fertilization

245 rates. Oocytes were spherical, they had no visible germinal vesicle and were released in batches

246 of 10-80 at a time. They were mostly negatively buoyant, however, they remained in suspension

247 for several hours due to water movement within the aquaria. Average oocyte diameter was 365.4

$248 \pm 24.2 \mu \mathrm{m}$. Gamete release was slow and sometimes continued for 1-3 hours. It happened

249 multiple times a day (every 2-3 hours) for a week and continued with lower frequency (every 1-3

250 days) for approximately a month. Release occurred both during day and night hours and did not

251 seem to follow any circadian pattern.

252 Embryonic and larval development

253 Cell division was always equal but cleavage varied highly among stages and embryos. It was not

254 possible to determine the timing of the first division after spawning. Cytokinesis was never

255 visible for the 2-cell stage, in which cleavage seemed to be always superficial (Fig. 1B). During

256 the following stages, cleavage varied from radial to pseudospiral and in some cases superficial,

257 leading to embryos with substantial differences in shape. Development always led to a hollow

258 blastula (Fig. 1G) followed by gastrulation and the formation of planula larvae without visible

259 oral pore (Fig. 1I). Cleavage and cell division did not differ between the two rearing

260 temperatures. 
261 At $13^{\circ} \mathrm{C}$, all embryos reached the blastula stage within $10 \mathrm{~h}$ and the early gastrula stage within

262 48h (Fig. 2). After $72 \mathrm{~h}$ all embryos reached the late gastrula stage and could perform slow,

263 mainly rotating movements by cilia, while fully competent, swimming planulae were formed

264 after 96h (4 days). During their development, embryos were negatively buoyant and accumulated

265 at the bottom of the flasks. In the first batch this resulted in the formation of embryo

266 aggregations and abnormal embryo development. This issue was solved by adding slight aeration

267 that ensured water and oxygen circulation within the flasks. At $15^{\circ} \mathrm{C}$, during the first 6 hours

268 cleavage seemed to be occurring at similar intervals until reaching the blastula stage (Fig. 2),

269 however, embryos reached the late gastrula and subsequently the planula stage approximately

$27024 \mathrm{~h}$ (after $72 \mathrm{~h}$ ) earlier than embryos reared at $13^{\circ} \mathrm{C}$ (Fig. 2).

271 Embryos between the 2-cell and 32-cell stage obtained variable shapes (Fig. 1) and their volume

272 was on average $0.03 \pm 0.0073 \mathrm{~mm}^{3}$. Subsequently, during the 64-cell stage and blastula they

273 turned more spherical but had a similar volume range $\left(0.03 \pm 0.005 \mathrm{~mm}^{3}\right)$. After reaching the

274 planula stage, embryos increased significantly in size (Table 1) and planulae reached $0.28 \pm 0.1$

$275 \mathrm{~mm}^{3}$ on day 4 and $0.67 \pm 0.28 \mathrm{~mm}^{3}$ on day 14 , with measurements on day 14 displaying

276 substantial variability. Mature planulae displayed the capacity to change their shape between

277 spherical and elongated, and more elongated larvae were observed on day 14 compared to day 4

278 (Figure S1). This was also confirmed from the LW ratio which presented a non-significant

279 decrease from late gastrula embryos $\left(1.49 \pm 0.17 \mathrm{~mm}^{3}\right)$ to planulae on day $4\left(1.22 \pm 0.29 \mathrm{~mm}^{3}\right)$

280 but increased significantly (Table 1) on day $14\left(2.02 \pm 0.45 \mathrm{~mm}^{3}\right)$. Embryo sizes were not

281 statistically different between the two temperatures (Table 1). Planulae on day 4 had significantly

282 higher $\mathrm{LW}$ ratios at $15^{\circ} \mathrm{C}(\mathrm{LW}=1.59 \pm 0.39$; Table 1$)$, showing a tendency to maintain a more

283 elongated shape than at $13^{\circ} \mathrm{C}$ (Fig. S1). 
284 Embryo and larval survival

285 In both temperatures, survival differed substantially among batches (Fig. S2). In most batches

286 reared at $13^{\circ} \mathrm{C}$, a sharp decline in survival rates was observed during the first 48 hours, after

287 which a more moderate mortality rate was established (Fig. 3). In the same temperature

288 treatment, median survival time, i.e. time when mortality reached 50\%, was 11 days while

289 survival after 36 days was $16.4 \%$. At $15^{\circ} \mathrm{C}$, the average mortality rate seemed to be more

290 constant (Fig. 3). Median survival time was 5 days longer than at $13^{\circ} \mathrm{C}$ (16 days), however, final

291 survival after 36 days was slightly lower (12.6\%). Overall, these differences were not statistically

292 significant according to the log-rank test ( $p=0.05$; Fig. 3 ).

293

294 Swimming behaviour

295 Planulae remained mostly at the bottom of the culture flasks, where they displayed slight

296 rotational and unidirectional movements. They rarely became waterborne without the aid of

297 water movement. Once in the water column, larvae did not show a specific swimming pattern but

298 followed random trajectories. Overall, for larvae reared under $13^{\circ} \mathrm{C}, 51.2 \pm 14.2 \%$ of the

299 recorded larval tracks were directed upwards while $50.7 \pm 6.33 \%$ were directed downwards. It

300 was not clear if downward movement involved swimming or just sinking. The proportion of

301 upward/downward swimming larvae did not change significantly with time (Table 1). Larvae

302 displayed an average swimming speed of $0.24 \pm 0.16 \mathrm{~mm} \mathrm{~s}^{-1}$ on day 4 and $0.36 \pm 0.21 \mathrm{~mm} \mathrm{~s}^{-1}$ on

303 day 15. Swimming speed did not differ significantly between upward and downward movements

304 (Table 1) but it was significantly higher on day 15 compared to day 4 (Table 1). 
305 Swimming velocity for larvae reared under $15{ }^{\circ} \mathrm{C}$ was similar between upward and downward

306 swimming (Table 1) and increased slightly but significantly with time (Table 1), from $0.4 \pm 0.24$

$307 \mathrm{~mm} \mathrm{~s}^{-1}$ on day 4 to $0.44 \pm 0.23 \mathrm{~mm} \mathrm{~s}^{-1}$ on day 15 . Overall, $52.7 \%$ of the recorded tracks were

308 directed downwards and the proportion of upward/downward swimming tracks did not differ

309 significantly between dates (Table 1). Larvae swimming velocity was significantly higher under

$31015{ }^{\circ} \mathrm{C}$ compared to $13{ }^{\circ} \mathrm{C}$, (Fig. 4) both on day 4 and day 15 (Table 1 ).

\section{Pelagic phase and settlement}

312 The proportion of planulae decreased substantially during the course of the experiment, mainly

313 due to high mortality (Fig. 4A). The surviving planulae followed slightly different trends

314 between the two temperatures with planulae under $15^{\circ} \mathrm{C}$ remaining in the pelagic phase for a

315 longer period (Fig. 4B), a difference that was statistically significant (Table 1). In both

316 temperatures, after day 36 only a minimal proportion of larvae remained (Fig. 4A) and the last

317 free swimming planulae were observed on day 39.

318 Larvae started settling on day 14 under $13^{\circ} \mathrm{C}$ and on day 17 under $15^{\circ} \mathrm{C}$. Under both

319 experimental temperatures, larvae settled on the flask walls and plastic slides whereas no larvae

320 attached to the provided basalt rock. Since the addition of substrate did not have any effect on

321 settlement behaviour, data from all flasks, i.e. with and without provided substrate, were pooled

322 together for further analysis. All settled larvae underwent metamorphosis. Larvae firstly obtained

323 a pear-like shape and subsequently became rounder, gradually forming a polyp base, mouth and

324 mesenteries (Fig. 5A). Fully developed primary polyps were formed within approximately 2-3

325 days, after the formation of tentacles, sclerites and tentacle pinnules (Fig. 5B). In both rearing

326 temperatures, the number of settled larvae corresponded to a very low proportion of the initial 
327 pool of planulae, corresponding to $3.21 \%$ (11 larvae) under $13^{\circ} \mathrm{C}$ and $1.46 \%$ (5 larvae) under

$32815^{\circ} \mathrm{C}$. Nevertheless, surviving planulae displayed slightly but significantly different trends

329 during the course of the study (Table 1), with a larger proportion of larvae settling earlier under

$33013^{\circ} \mathrm{C}$ than under $15^{\circ} \mathrm{C}$ (Fig. 4). A high variance was observed on the estimates of the average

331 proportion of settled larvae (Fig. 4) among batches at $13^{\circ} \mathrm{C}$, mainly due to a single batch in

332 which very few larvae settled throughout the study period.

333 After day 20, an increasing proportion of the surviving larvae initiated metamorphosis without

334 settling (Fig. 4), in both temperature regimes. This form of pelagic metamorphosis started with

335 planula larvae obtaining a pear shape (Fig. 6A) and continued with formation of mouth,

336 mesenteries, tentacles and finally sclerites (Fig. 6B, 6C). Metamorphosis from planula larva to

337 primary polyp took approximately 2-3 days. None of the larvae that displayed pelagic

338 metamorphosis settled during the course of the study. Metamorphosed larvae were still able to

339 get transported by water movements but displayed limited swimming ability. The trend of

340 pelagically metamorphosed larvae appeared to be significantly different between the two

341 temperatures (Table 1), but the constructed model was heavily influenced by one batch under

$34215^{\circ} \mathrm{C}$ in which all remaining planulae on day 31 metamorphosed pelagically and subsequently

343 presented deformations and deceased (Fig. 4B). Overall, during the experimental period 26

344 larvae metamorphosed pelagically under $13^{\circ} \mathrm{C}$ and 28 under $15^{\circ} \mathrm{C}$, representing only $7.5 \%$ and

$3458.18 \%$ of the initial planulae pool. Deformed larvae were observed in both temperatures but

346 represented a small proportion of the initial pool $\left(2.02 \%\right.$ under $13^{\circ} \mathrm{C}$ and $1.16 \%$ under $\left.15^{\circ} \mathrm{C}\right)$.

347 Under $13^{\circ} \mathrm{C}$, they started appearing on day 24 (Fig. 4B) but remained in low numbers throughout

348 the experimental period. Under $15^{\circ} \mathrm{C}$, they appeared 2 days later, but reached significantly higher 
349 proportions after day 35 (Table 1, Fig. 4B). Most of these late deformations under $15^{\circ} \mathrm{C}$ were

350 observed in pelagically metamorphosed larvae (Fig. 6D).

\section{Discussion}

353 So far, studies on the biology and ecology of deep-sea octocorals have focused mainly on the

354 adult stage (Watling et al., 2011), with very few studies tackling early life history stages (Cordes

355 et al., 2001, Sun et al., 2010; 2011). To our knowledge, the present study is the first to provide a

356 detailed insight to the larval biology of a deep-sea octocoral species including embryo and larval

357 development, larval survival, swimming and settlement behaviour, which are essential variables

358 to understand dispersal and connectivity in the deep-sea (Gary et al., 2020).

359 In our study, it was not clear if spawning was actually induced, assisted or just coincided with 360 sperm enrichment, due to the limited time interval between sperm enrichment and the first

361 gamete release. Repetitive release of gametes or planulae within a specific period is common

362 among octocorals, including tropical broadcast spawning (Pakes and Woolakott, 2008; Wells et

363 al., 2020), temperate brooding (Weinberg and Weinberg, 1979; Martínez-Quintana, 2015) and

364 deep-sea brooding species (e.g. Sun et al., 2011). This strategy may increase the probability that

365 some embryos and larvae develop under optimal conditions (Kahng et al., 2008). In species with

366 this behaviour, studying the effects of different environmental variables on embryo development

367 is crucial, as embryos of different cohorts are likely to be released under different environmental

368 conditions including temperature, salinity, $\mathrm{pH}$ and food availability.

369 Embryo and larval development of Dentomuricea aff. meteor had many similar characteristics

370 with other octocoral species. Unequal cleavage that ranges from radial to pseudospiral is 
371 common among cnidarians (Fritzenwanker et al., 2007), including tropical brooding (Benayahu 372 and Loya, 1983; Dahan and Benayahu, 1998) and broadcast spawning (Mandelberg-Aharon and

373 Benayahu, 2015) octocorals. Superficial cleavage, like the one observed in $D$. aff. meteor is

374 frequently encountered in embryos with high amounts of yolk reserves (Scriba, 2015), indicating

375 a lecithotrophic larvae which was also confirmed by the absence of oral opening before

376 metamorphosis. Larval size was also comparable to that of other octocoral species (Table 2).

377 Overall, these findings suggest that some reproductive and larval characteristics might be

378 conserved among taxonomically related groups, despite local adaptations due to depth and other

379 habitat limitations.

380 Temperature is considered one of the main factors affecting larval biology, with higher

381 temperatures usually resulting in faster developmental rates (Hoegh-Guldberg and Pearse, 1995).

382 Our results were consistent with this premise, with larvae reaching the planula stage 24 hours

383 earlier at $15^{\circ} \mathrm{C}$ when compared to $13{ }^{\circ} \mathrm{C}$. This difference in developmental time is likely the

384 drive between the differences in the LW ratios, since planulae tend to be more elongated with

385 age. The different developmental rates did not affect survival which was similar and very low for

386 both temperatures but varied substantially among batches. Since it was not possible to observe

387 which female colonies participated in each gamete release, the possibility that first batches had

388 lower survival cannot be excluded. Larval characteristics such as size and longevity have been

389 shown to vary between cohorts in many marine larvae (Marshall et al., 2008; Cumbo et al., 2012;

390 Martínez-Quintana et al., 2015). Such variability between offspring has been considered an

391 adaptive strategy to increase offspring survival in species that inhabit unstable environments

392 (Cooper and Caplan, 1982; Marshall et al., 2008). 
393 Most deep-sea octocoral planulae studied so far, displayed low mobility, negative buoyancy and 394 crawling (e.g. Drifa glomerata, Sun et al., 2010; Duva florida, Sun et al., 2011) or very limited 395 swimming capacity (e.g. Drifa sp., Sun et al., 2010). On the contrary, larvae of $D$. aff. meteor 396 were active swimmers but initiated swimming only after stimulation, a behaviour also recorded 397 in Corallium rubrum (Martínez-Quintana et al., 2015). Swimming in D. aff. meteor was random, 398 as revealed by the similar proportion of upward and downward swimming. When compared to 399 other deep-sea broadcast spawning corals, such as the scleractinian Lophelia pertusa, D. aff. 400 meteor had lower swimming capabilities, especially since L. pertusa displayed intense, negative 401 geotactic behaviour (Larsson et al., 2014). Swimming velocity of $D$. aff. meteor was comparable 402 to that of C. rubrum (Table 2) and L. pertusa (Larsson et al., 2014), but larvae of these species 403 were maintained under different temperature regimes $\left(19-20{ }^{\circ} \mathrm{C}\right.$ for $C$. rubrum, Martínez404 Quintana et al., 2015; 8-12 ${ }^{\circ} \mathrm{C}$ for L. pertusa, Larsson et al., 2014). Temperature can affect both 405 larval physiology and water characteristics since higher temperature often causes a decrease in 406 viscosity and increase in larval metabolic rates (von Herbing, 2002). Both effects can result in 407 higher swimming velocity and are likely to be associated with the higher larval swimming speed 408 of $D$. aff. meteor under $15^{\circ} \mathrm{C}$. Nonetheless, metabolism is not the only physiological process 409 affected by temperature and larvae display physiological limits, which need to be further studied 410 for the target species.

411 Larval planktonic period can be divided in two phases, an obligatory phase that lasts until the 412 onset of developmental competence (the ability to respond to settlement cues) and a facultative 413 phase that depends on settlement behaviour in response to the existence of certain substrate 414 characteristics (competency window, Elkin and Marshall, 2007). In the present study, both 415 phases were characterized by high mortality, leading to a loss of more than $50 \%$ of planulae 
416 before the defined onset of competency. Moreover, the onset of competency was inferred by the

417 first larval settlement since larvae did not display any specific geotactic or bottom probing

418 behaviour, but it is possible that larvae had entered competency before actually settling.

419 Settlement rates were low and a higher proportion of the surviving larvae metamorphosed

420 without settling. These are strong indications that adequate settlement surfaces and cues were not

421 provided during the study. It is thus likely that larvae were forced to proceed to the next

422 ontogenetic phases (settlement and metamorphosis) due to the lack of energy reserves. This

423 phenomenon has been tentatively explained by the "desperate larvae hypothesis" (Gibson, 1995;

424 Marshall and Keough, 2003), which states that the duration of the planktonic phase is likely

425 determined by the availability of energetic reserves (Wendt, 2000) and therefore non-feeding

426 larvae can only delay settlement and metamorphosis until reaching a specific reserve level (Elkin

427 and Marshall, 2007).

428 Remarkably, settlement only took place on plastic surfaces while none of the larvae attached on

429 the provided basalt rock. This was slightly unexpected since $D$. aff. meteor has been observed to

430 colonize basalt rock in seamounts in the Azores. It is highly possible that this was due to the lack

431 of bacterial biofilm on the rock, which has been shown as an important settlement clue for other

432 invertebrates (Hadfield et al 2011). Moreover, the provided rock occupied a very small area

433 compared to the flask walls. Settling on plastic is not uncommon among octocorals (Lasker and

434 Kim, 1996: Freire et al., 2019; Carugati et al., 2020) but further studies with more settlement

435 surfaces are essential to clarify the settlement requirements of the target species. Pelagic

436 metamorphosis of planulae into polyps has also been reported for many octocorals from shallow

437 tropical (Ben-David-Zaslow and Benayahu, 1996; Lasker and Kim, 1996), to temperate (Linares

438 et al., 2008) and deep-sea species (Sun et al., 2011). In some corals, pelagic polyps can display 
439 high survival and dispersal potential (Mizrahi et al., 2014) and have the ability to feed (Zazlow 440 and Benayahu, 1996; Linares et al., 2008). In our study, pelagic polyps displayed high mortality

441 but this could be due to the absence of sufficient or adequate food sources. Nevertheless, pelagic

442 metamorphosis might provide a way to acquire feeding structures and allows the acquisition of

443 energy while waiting for the right settlement cue. In the case of $D$. aff. meteor, the high

444 proportion of surviving larvae that displayed this behaviour supports the hypothesis that larvae

445 had limited energy reserves and possibly reached their maximum longevity during the

446 experiment.

447 Under higher temperature, larvae of $D$. aff. meteor remained longer in the pelagic phase and 448 displayed lower settlement rates. This was contrary to the expected outcome, since the higher 449 developmental rates observed under higher temperature are expected to be accompanied by 450 earlier competency and higher settlement rates (O'Connor et al., 2007; Heyward and Negri, 451 2010). Faster developmental rates, accompanied by decreased settlement under higher 452 temperatures $\left(+3^{\circ} \mathrm{C}\right)$ has been also reported for the tropical octocoral Heliopora coerulea 453 (Conaco et al., 2020). It is possible that these results are related to temperature-induced changes 454 in developmental and physiological mechanisms that were not evaluated in our study. For 455 example, it is possible that faster development under higher temperature was accompanied by 456 faster metabolic rates (O'Connor et al., 2007) and resulted in faster consumption of reserves, 457 leading to high rates of pelagic metamorphosis and deformations under the absence of proper 458 settlement cues. Ontogeny depends on certain developmental processes and their timing and 459 while developmental rate can be plastic, changes in timing are likely to have consequences on 460 structure and function, ultimately affecting individual performance (Kováč, 2002). 
461 Overall, the embryonic and larval characteristics of $D$. aff. meteor suggest a higher dispersal 462 potential than most deep-sea octocorals studied so far (Table 2). However, when compared to 463 other deep-sea species, the dispersal capacity of $D$. aff. meteor appears to be limited. For 464 example, the scleractinian L. pertusa delayed the onset of competency up to 3-5 weeks from 465 spawning, displayed active upward swimming and survived without settlement for 466 approximately a year (Larsson et al., 2014). Similarly, other deep-sea species such as the bivalve 467 Bathymodiolus childressi and the gastropod Bathynerita naticoidea display longer longevities 468 (approximately one year) and enhanced upward swimming which indicate much higher dispersal 469 potential than D. aff. meteor (Arellano and Young, 2009). The larvae of these deep-sea species are planktotrophic and therefore are not constrained by reserve availability. Our results highlight

471 that the energy reserves of $D$. aff. meteor are a great limitation for many of its larval traits, 472 especially its longevity and behaviour regarding settlement and metamorphosis. While its 473 swimming behaviour is very likely to allow it to disperse among regional seamounts with the aid 474 of local hydrodynamics, its short longevity is indicative of its narrow regional distribution in the 475 North Mid-Atlantic Ridge, especially when compared with the wide distributions of L. pertusa 476 and $B$. childressi.

477 Since the two temperature regimes used in this study are likely to be experienced by embryos of 478 the target species in their natural environment, our results highlight how small changes in 479 temperature can affect embryo development and larval characteristics, such as swimming 480 velocity and settlement behaviour. Climate change is expected to cause changes in ocean 481 circulation (Sweetmann et al., 2020) which can modify the water mass dynamics and alter the 482 physicochemical characteristics encountered by embryos and larvae (van Gennip et al., 2016; 483 Claret et al., 2018). Under these circumstances, baseline information on the responses of early 
484 life history stages under variable conditions is essential to predict potential effects on dispersal 485 and connectivity. For example, embryos and larvae of the Antarctic echinoderm Sterechinus 486 neumayeri can withstand high pressures only under a narrow temperature interval which can be

487 encountered in specific water masses that allowed the species to disperse to greater depths (Tyler 488 et al., 2000). In the case of this species, potential changes in regional circulation, may affect or 489 even disrupt connectivity between shallow and deeper populations. Moreover, larval dispersal 490 and success are important features not only from an ecological but also from an evolutionary

491 perspective, as their adaptive significance can define the selection of reproductive strategies such 492 as reproductive timing (Olive, 1992, Crowder et al. 2014; Fan et al., 2017). In deep-sea corals, 493 reproductive timing has been discussed in relation to the seasonal constraints of adult 494 reproductive physiology (e.g. Orejas et al., 2002; Waller et al., 2014) but its relation to larval 495 survival and success has not been addressed so far. Further studies on the effect of temperature on larval development, physiology and behaviour are therefore essential to obtain a holistic view of the potential impacts of climate change on deep-sea corals and communities.

\section{Conclusions}

In our study, we provided a detailed description of embryo and larval characteristics of the species $D$. aff. meteor. To our knowledge, this is the first systematic description of the early life history traits of a deep-sea octocoral. Our results suggest that $D$. aff. meteor larvae are lecithotrophic with development similar to other octocorals and low dispersal capacity compared to other deep-sea species. Rearing at different temperatures did not affect survival, but significant effects were detected on the rate of embryo development, swimming speed and settlement behaviour which in the field can potentially alter larval dispersal and ultimately success. Deep-sea octocorals are receiving increasing attention as a growing number of studies 
507 focus on the habitat requirements and environmental conditions shaping deep-sea communities

508 (Radice et al., 2016; Barbosa et al., 2020; Morato et al., 2020). However, understanding species

509 distributions requires further knowledge on their early life history biology and dispersal, as these

510 play a key role in the successful occupation of available suitable habitat (Schurr et al., 2007;

511 Robinson et al., 2011). As attempts of biophysical dispersal modelling are increasing in the deep-

512 sea (Hilario et al., 2015; Ross et al., 2016), further biological data to feed into these models are

513 essential to obtain a better understanding of deep-sea ecosystems.

515 Acknowledgements

516 We are very grateful to Cristina Gutiérrez-Zárate and the scientists and crew of R/V Arquipelago

517 for specimen and data collection, as well as to Eva Giacomello, Gonçalo Graça and Robert

518 Priester for compiling the database of the environmental data used in this study.

\section{References}

520

521

522

523

524

525

526
Arellano SM, Van Gaest AL, Johnson SB, Vrijenhoek RC, Young CM. 2014. Larvae from deepsea methane seeps disperse in surface waters. Proceedings of the Royal Society B: Biological Sciences 281:20133276. DOI: 10.1098/rspb.2013.3276.

Arellano SM, Young CM. 2011. Temperature and salinity tolerances of embryos and larvae of the deep-sea mytilid mussel Bathymodiolus childressi. Marine Biology 158:2481-2493. DOI: $10.1007 / \mathrm{s} 00227-011-1749-9$.

Arellano SM, Young CM. 2009. Spawning, development, and the duration of larval life in a deep-sea cold-seep mussel. The Biological Bulletin 216:149-162. DOI: 10.1086/bblv216n2p149.

Asoh K, Yoshikawa T. 2002. The role of temperature and embryo development time in the diel timing of spawning in a coral-reef damselfish with high-frequency spawning synchrony. Environmental Biology of Fishes 64:379-392. DOI: 10.1023/A:1016177512353. 
532

533

534

535

536

537

538

539

540

541

542

543

544

545

546

547

548

549

550

551

552

553

554

555

556

557

558

559

560

561

562

563

564

565

Barbosa RV, Davies AJ, Sumida PYG. 2020. Habitat suitability and environmental niche comparison of cold-water coral species along the Brazilian continental margin. Deep Sea Research Part I: Oceanographic Research Papers 155:103147. DOI: 10.1016/J.DSR.2019.103147.

Benayahu Y, Loya Y. 1983. Surface brooding in the Red Sea soft coral Parerythropodium fulvum fulvum (Forkal, 1775). The Biological bulletin 165:353-369. DOI: $10.2307 / 1541201$.

Bishop CD, Huggett MJ, Heyland A, Hodin J, Brandhorst BP. 2006. Interspecific variation in metamorphic competence in marine invertebrates: The significance for comparative investigations into the timing of metamorphosis. In: Integrative and Comparative Biology. Oxford Academic, 662-682. DOI: 10.1093/icb/ic1043.

Braga-Henriques A, Porteiro FM, Ribeiro P a., De Matos V, Sampaio Í, Ocaña O, Santos RS. 2013. Diversity, distribution and spatial structure of the cold-water coral fauna of the Azores (NE Atlantic). Biogeosciences 10:4009-4036. DOI: 10.5194/bg-10-4009-2013.

Brooke SD, Watts MW, Heil AD, Rhode M, Mienis F, Duineveld GCA, Davies AJ, Ross SW. 2017. Distributions and habitat associations of deep-water corals in Norfolk and Baltimore Canyons, Mid-Atlantic Bight, USA. Deep Sea Research Part II: Topical Studies in Oceanography 137:131-147. DOI: 10.1016/J.DSR2.2016.05.008.

Bryan TL, Metaxas A. 2006. Distribution of deep-water corals along the North American continental margins: Relationships with environmental factors. Deep Sea Research Part I: Oceanographic Research Papers 53:1865-1879. DOI: 10.1016/J.DSR.2006.09.006.

Byrne M. 2012. Global change ecotoxicology: identification of early life history bottlenecks in marine invertebrates, variable species responses and variable experimental approaches. Marine environmental research 76: 3-15.

Carugati L, Bramanti L, Giordano B, Pittura L, Cannas R, Follesa MC, Pusceddu A, Cau A. 2021. Colonization of plastic debris by the long-lived precious red coral Corallium rubrum: New insights on the "plastic benefits" paradox. Marine Pollution Bulletin 165:112104. DOI: 10.1016/j.marpolbul.2021.112104.

Claret M, Galbraith ED, Palter JB, Bianchi D, Fennel K, Gilbert D, Dunne JP. 2018. Rapid coastal deoxygenation due to ocean circulation shift in the northwest Atlantic. Nature Climate Change 8:868-872. DOI: 10.1038/s41558-018-0263-1.

Coelho M, Lasker H. 2016. Larval behavior and settlement dynamics of a ubiquitous Caribbean octocoral and its implications for dispersal. Marine Ecology Progress Series 561:109-121. DOI: $10.3354 /$ meps 11941. 
566

567

568

569

570

571

572

573

574

575

576

577

578

579

580

581

582

583

584

585

586

587

588

589

590

591

592

593

594

595

596

597

598

599

Conaco C, Cabaitan PC. 2020. Influence of salinity and temperature on the survival and settlement of Heliopora coerulea larvae. Marine Pollution Bulletin 150:110703. DOI: 10.1016/j.marpolbul.2019.110703.

Cooper WS, Kaplan RH. 1982. Adaptive “coin-flipping": a decision-theoretic examination of natural selection for random individual variation. Journal of Theoretical Biology 94:135151. DOI: 10.1016/0022-5193(82)90336-8.

Cordes EE, Nybakken JW, VanDykhuizen G. 2001. Reproduction and growth of Anthomastus ritteri (Octocorallia: Alcyonacea) from Monterey Bay, California, USA. Marine Biology 138:491-501. DOI: 10.1007/s002270000470.

Cowen RK, Gawarkiewicz G, Pineda J, Thorrold SR, Werner FE. 2007. Population connectivity in marine systems: An overview. Oceanography 20:14-21. DOI: 10.2307/24860093.

Cowen RK, Sponaugle S. 2009. Larval dispersal and marine population connectivity. Annual review of marine science 1:443-66. DOI: 10.1146/annurev.marine.010908.163757.

Crowder C, Liang W, Weis V, Fan T. 2014. Elevated temperature alters the lunar timing of planulation in the brooding coral Pocillopora damicornis. PLoS ONE 9:e107906.

Cumbo VR, Fan TY, Edmunds PJ. 2012. Physiological development of brooded larvae from two pocilloporid corals in Taiwan. Marine Biology 159:2853-2866. DOI: 10.1007/s00227-0122046-y.

Dahan M, Benayahu Y. 1997. Clonal propagation by the azooxanthellate octocoral Dendronepththya hemprichi. Coral Reefs 16:5-12. DOI: 10.1007/s003380050053.

Dong Y, Peng CYJ. 2013. Principled missing data methods for researchers. SpringerPlus 2:1-17. DOI: $10.1186 / 2193-1801-2-222$.

Elkin C, Marshall D. 2007. Desperate larvae: influence of deferred costs and habitat requirements on habitat selection. Marine Ecology Progress Series 335:143-153. DOI: $10.3354 / \operatorname{meps} 335143$.

Fan T, Hsieh Y, Lin K, Kuo F, Soong K, McRae C, Edmunds P, Fang L. 2017. Plasticity in lunar timing of larval release of two brooding pocilloporid corals in an internal tide-induced upwelling reef. Marine Ecology Progress Series 569:117-127. DOI: 10.3354/meps12071.

Figueiredo J, Baird AH, Harii S, Connolly SR. 2014. Increased local retention of reef coral larvae as a result of ocean warming. Nature Climate Change 4:498-502. DOI: 10.1038/nclimate2210.

Freire I, Gutner-Hoch E, Muras A, Benayahu Y, Otero A. 2019. The effect of bacteria on planula-larvae settlement and metamorphosis in the octocoral Rhytisma fulvum fulvum. PLOS ONE 14:e0223214. DOI: 10.1371/journal.pone.0223214.

Peer] reviewing PDF | (2020:12:56492:2:0:NEW 18 May 2021) 
600

601

602

603 604

605

606

607

608

609

610

611

612

613

614

615

616

617

618

619

620

621

622

623

624

625

626

627

628

629

630

631

632

633
Fritzenwanker JH, Genikhovich G, Kraus Y, Technau U. 2007. Early development and axis specification in the sea anemone Nematostella vectensis. Developmental Biology 310:264279. DOI: 10.1016/J.YDBIO.2007.07.029.

Gary S, Fox A, Biastoch A, Roberts JM. 2020. Larval behaviour, dispersal and population connectivity in the deep sea. Scientific Reports 10:1-12.

van Gennip SJ, Popova EE, Yool A, Pecl GT, Hobday AJ, Sorte CJB. 2017. Going with the flow: the role of ocean circulation in global marine ecosystems under a changing climate. Global Change Biology 23:2602-2617. DOI: 10.1111/gcb.13586.

Gibson G. 1995. Why be choosy? Temporal changes in larval sensitivity to several naturallyoccurring metamorphic inducers in the opisthobranch Haminaea callidegenita. Journal of Experimental Marine Biology and Ecology 194:9-24. DOI: 10.1016/0022-0981(95)000755.

Graham EM, Baird AH, Connolly SR. 2008. Survival dynamics of scleractinian coral larvae and implications for dispersal. Coral Reefs 27:529-539. DOI: 10.1007/s00338-008-0361-z.

Hadfield MG. 2011. Biofilms and marine invertebrate larvae: What bacteria produce that larvae use to choose settlement sites. Annual Review of Marine Science 3:453-470. DOI: 10.1146/annurev-marine-120709-142753.

Harrison PL, Wallace C. 1990. Reproduction, dispersal and recruitment of scleractinian corals. In: Dubinksy Z ed. Ecosystems of the World, 25. Coral Reefs. Amsterdam: Elsevier Science, 133-207.

Herbing IH von. 2002. Effects of temperature on larval fish swimming performance: the importance of physics to physiology. Journal of Fish Biology 61:865-876. DOI: 10.1111/j.1095-8649.2002.tb01848.x.

Heyward AJ, Negri AP. 2010. Plasticity of larval pre-competency in response to temperature: Observations on multiple broadcast spawning coral species. Coral Reefs 29:631-636. DOI: 10.1007/s00338-009-0578-5.

Hilário A, Metaxas A, Gaudron SM, Howell KL, Mercier A, Mestre NC, Ross RE, Thurnherr AM, Young C. 2015. Estimating dispersal distance in the deep sea: Challenges and applications to marine reserves. Frontiers in Marine Science 2:6. DOI: 10.3389/fmars.2015.00006.

Hoegh-Guldberg O, Pearse JS. 1995. Temperature, Food Availability, and the Development of Marine Invertebrate Larvae. American Zoologist 35:415-425. DOI: 10.1093/icb/35.4.415.

Kaplan EL, Meier P. 1958. Nonparametric Estimation from Incomplete Observations. Journal of the American Statistical Association 53:457-481. DOI: 10.1080/01621459.1958.10501452.

Peer) reviewing PDF | (2020:12:56492:2:0:NEW 18 May 2021) 
634 Kassambara A, Kosinski M, Biecek P. 2019. survminer: Drawing Survival Curves using 635 'ggplot2'. R package version 0.4.6. https://CRAN.R-project.org/package=survminer

636

637

638

639

640

641

642

643

644

645

646

647

648

649

650

651

652

653

654

655

656

657

658

659

660

661

662

663

664

665

666

667
Kahng SE, Benayahu Y, Wagner D, Rothe N. 2008. Sexual reproduction in the invasive octocoral Carijoa riisei in Hawaii. Bulletin of Marine Science 82(1):1-7.

Kipson S, Linares C, Čižmek H, Cebrián E, Ballesteros E, Bakran-Petricioli T, Garrabou J. 2015. Population structure and conservation status of the red gorgonian Paramuricea clavata (Risso, 1826) in the Eastern Adriatic Sea. Marine Ecology 36:982-993. DOI: 10.1111/maec.12195.

Kováč V. 2002. Synchrony and heterochrony in ontogeny (of fish). Journal of Theoretical Biology 217:499-507. DOI: 10.1006/jtbi.2002.3043.

Kowarik A, Templ M. 2016. Imputation with the R Package Vim. Journal of Statistical Software 74:1-16. DOI: $10.18637 /$ jss.v074.i07.

Larsson AI, Järnegren J, Strömberg SM, Dahl M, Lundälv T, Brooke S. 2014. Embryogenesis and larval biology of the cold-water coral Lophelia pertusa. PLoS ONE 9.7:e102222.

Lasker HR, Kim K. 1996. Larval development and settlement behavior of the gorgonian coral Plexaura kuna (Lasker, Kim and Coffroth). Journal of Experimental Marine Biology and Ecology 207:161-175. DOI: 10.1016/S0022-0981(96)02625-1.

Levin LA, Bett BJ, Gates AR, Heimbach P, Howe BM, Janssen F, McCurdy A, Ruhl HA, Snelgrove P, Stocks KI, Bailey D, Baumann-Pickering S, Beaverson C, Benfield MC, Booth DJ, Carreiro-Silva M, Colaço A, Eblé MC, Fowler AM, Gjerde KM, Jones DOB, Katsumata K, Kelley D, Le Bris N, Leonardi AP, Lejzerowicz F, Macreadie PI, McLean D, Meitz F, Morato T, Netburn A, Pawlowski J, Smith CR, Sun S, Uchida H, Vardaro MF, Venkatesan R, Weller RA. 2019. Global Observing Needs in the Deep Ocean. Frontiers in Marine Science 6:241. DOI: 10.3389/fmars.2019.00241.

Levitan DR, Terhorst CP, Fogarty ND. 2007. The risk of polyspermy in three congeneric sea urchins and its implications for gametic incompatibility and reproductive isolation. Evolution 61:2007-2014. DOI: 10.1111/j.1558-5646.2007.00150.x.

Linares C, Coma R, Mariani S, Díaz D, Hereu B, Zabala M. 2008. Early life history of the Mediterranean gorgonian Paramuricea clavata: implications for population dynamics. Invertebrate Biology 127:1-11. DOI: 10.1111/j.1744-7410.2007.00109.x.

Mandelberg-Aharon Y, Benayahu Y. 2015. Reproductive features of the Red Sea octocoral Sarcophyton auritum (Verseveldt \& Benayahu, 1978) are uniform within generic boundaries across wide biogeographical regions. Hydrobiologia 759:119-132. DOI: $10.1007 / \mathrm{s} 10750-015-2225-1$. 
668

669

670

671

672

673

674

675

676

677

678

679

680

681

682

683

684

685

686

687

688

689

690

691

692

693

694

695

696

697

698

699

700

701

702

703

Marshall DJ, Keough M. 2003. Variation in the dispersal potential of non-feeding invertebrate larvae: the desperate larva hypothesis and larval size. Marine Ecology Progress Series 255:145-153. DOI: $10.3354 /$ meps255145.

Marshall DJ, Bonduriansky R, Bussière LF. 2008. Offspring size variation within broods as a bet-hedging strategy in unpredictable environments. Ecology 89:2506-2517. DOI: 10.1890/07-0267.1.

Marshall DJ, Morgan SG. 2011. Ecological and evolutionary consequences of linked life-history stages in the sea. Current Biology 21:718-725. DOI: 10.1016/j.cub.2011.08.022.

Martínez-Quintana A, Bramanti L, Viladrich N, Rossi S, Guizien K. 2014. Quantification of larval traits driving connectivity: the case of Corallium rubrum (L. 1758). Marine Biology 162:309-318. DOI: 10.1007/s00227-014-2599-z.

Melzner F, Gutowska MA, Langenbuch M, Dupont S, Lucassen M, Thorndyke MC, Bleich M, Pörtner H-O. 2009. Physiological basis for high $\mathrm{CO}_{2}$ tolerance in marine ectothermic animals: pre-adaptation through lifestyle and ontogeny? Biogeosciences 6:2313-2331. DOI: 10.5194/bg-6-2313-2009.

Mercier A, Hamel J-F. 2011. Contrasting reproductive strategies in three deep-sea octocorals from eastern Canada: Primnoa resedaeformis, Keratoisis ornata and Anthomastus grandiflorus. Coral Reefs 30:337-350. DOI: 10.1007/s00338-011-0724-8.

Metaxas A, Saunders M. 2009. Quantifying the "Bio-" components in biophysical models of larval transport in marine benthic invertebrates: advances and pitfalls. Biological Bulletin 216:257-272. DOI: $10.2307 / 25548159$.

Miller KJ, Gunasekera RM. 2017. A comparison of genetic connectivity in two deep sea corals to examine whether seamounts are isolated islands or stepping stones for dispersal. Scientific Reports 7:46103. DOI: 10.1038/srep46103.

Mizrahi D, Navarrete SA, Flores AA V. 2014. Groups travel further: pelagic metamorphosis and polyp clustering allow higher dispersal potential in sun coral propagules. Coral Reefs 33:443-448. DOI: 10.1007/s00338-014-1135-4.

Morato T, González-Irusta J, Dominguez-Carrió C, Wei C, Davies A, Sweetman AK, Taranto GH, Beazley L, García-Alegre A, Grehan A, Laffargue P, Murillo FJ, Sacau M, Vaz S, Kenchington E, Arnaud-Haond S, Callery O, Chimienti G, Cordes E, Egilsdottir H, Freiwald A, Gasbarro R, Gutiérrez-Zárate C, Gianni M, Gilkinson K, Wareham Hayes VE, Hebbeln D, Hedges K, Henry L, Johnson D, Koen-Alonso M, Lirette C, Mastrototaro F, Menot L, Molodtsova T, Durán Muñoz P, Orejas C, Pennino MG, Puerta P, Ragnarsson SÁ, Ramiro-Sánchez B, Rice J, Rivera J, Roberts JM, Ross SW, Rueda JL, Sampaio Í, Snelgrove P, Stirling D, Treble MA, Urra J, Vad J, Oevelen D, Watling L, Walkusz W, Wienberg C, Woillez M, Levin LA, Carreiro-Silva M. 2020. Climate-induced changes in 
704

711

712

713

714

715

716

717

718

719

720

721

722

723

724

725

726

727

728

729

730

731

732

733

734

735

736

737

738

739

the suitable habitat of cold-water corals and commercially important deep-sea fishes in the North Atlantic. Global Change Biology 26:2181-2202. DOI: 10.1111/gcb.14996.

Morgan SG, Christy JH. 1995. Adaptive significance of the timing of larval release by crabs. The American Naturalist 145:457-479. DOI: 10.1086/285749.

Nishikawa A, Katoh M, Sakai K. 2003. Larval settlement rates and gene flow of broadcastspawning (Acropora tenuis) and planula-brooding (Stylophora pistillata) corals. Marine Ecology Progress Series 256:87-97. DOI: 10.3354/meps256087.

O’Connor MI, Bruno JF, Gaines SD, Halpern BS, Lester SE, Kinlan BP, Weiss JM. 2007. Temperature control of larval dispersal and the implications for marine ecology, evolution, and conservation. Proceedings of the National Academy of Sciences of the United States of America 104:1266-1271. DOI: 10.1073/pnas.0603422104.

Orejas C, Gili JM, Teixidó N, Gutt J, Arntz WE, Meeresforschung AP-. 2002. Distribution and reproductive ecology of the Antarctic octocoral Ainigmaptilon antarcticum in the Weddell Sea. Marine Ecology Progress Series 231:101-114.

Orejas C, Taviani M, Ambroso S, Andreou V, Bilan M, Bo M, Brooke S, Buhl-Mortensen P, Cordes E, Dominguez-Carrió C, Ferrier-Pagès C, Godinho A, Gori A, Grinyó J, GutiérrezZárate C, Hennige S, Jiménez C, Larsson AI, Lartaud F, Lunden J, Maier C, Maier SR, Movilla J, Murray F, Peru E, Purser A, Rakka M, Reynaud S, Roberts JM, Siles P, Strömberg SM, Thomsen L, van Oevelen D, Veiga A, Carreiro-Silva M. 2019. Cold-water coral in aquaria: Advances and challenges. A Focus on the Mediterranean. In: Springer, Cham, 435-471. DOI: 10.1007/978-3-319-91608-8_38.

Pakes MJ, Woollacott RM. 2008. Reproduction of the gorgonian Plexaura flexuosa in Bermuda. Journal of Experimental Marine Biology and Ecology 357:121-127. DOI: 10.1016/j.jembe.2008.01.003.

Przeslawski R, Byrne M, Mellin C. 2015. A review and meta-analysis of the effects of multiple abiotic stressors on marine embryos and larvae. Global Change Biology 21:2122-2140. DOI: $10.1111 / \mathrm{gcb} .12833$.

Radice VZ, Quattrini AM, Wareham VE, Edinger EN, Cordes EE. 2016. Vertical water mass structure in the North Atlantic influences the bathymetric distribution of species in the deepsea coral genus Paramuricea. Deep Sea Research Part I: Oceanographic Research Papers 116:253-263. DOI: 10.1016/J.DSR.2016.08.014.

Randall CJ, Szmant AM. 2009. Elevated temperature reduces survivorship and settlement of the larvae of the Caribbean scleractinian coral, Favia fragum (Esper). Coral Reefs 28:537-545. DOI: $10.1007 / \mathrm{s} 00338-009-0482-\mathrm{z}$.

Robinson LM, Elith J, Hobday AJ, Pearson RG, Kendall BE, Possingham HP, Richardson AJ. 2011. Pushing the limits in marine species distribution modelling: lessons from the land 
742

743

744

745

746

747

748

749

750

751

752

753

754

755

756

757

758

759

760

761

762

763

764

765

766

767

768

769

770

771

772

773

774

present challenges and opportunities. Global Ecology and Biogeography 20:789-802. DOI: 10.1111/j.1466-8238.2010.00636.x.

Ross RE, Nimmo-Smith WAM, Howell KL. 2016. Increasing the depth of current understanding: Sensitivity testing of deep-sea larval dispersal models for ecologists. PloS one 11:e0161220. DOI: 10.1371/journal.pone.0161220.

Sampaio Í, Freiwald A, Porteiro F, Menezes G, Carreiro-Silva M. 2019. Census of Octocorallia (Cnidaria: Anthozoa) of the Azores (NE Atlantic) with a nomenclature update. Zootaxa 4550:451. DOI: 10.11646/zootaxa.4550.4.1.

Santos M, Moita MT, Bashmachnikov I, Menezes GM, Carmo V, Loureiro CM, Mendonça A, Silva AF, Martins A. 2013. Phytoplankton variability and oceanographic conditions at Condor seamount, Azores (NE Atlantic). Deep Sea Research Part II: Topical Studies in Oceanography 98:52-62. DOI: 10.1016/J.DSR2.2013.05.037.

Schindelin J, Arganda-Carreras I, Frise E, Kaynig V, Longair M, Pietzsch T, Preibisch S, Rueden C, Saalfeld S, Schmid B, Tinevez JY, White DJ, Hartenstein V, Eliceiri K, Tomancak P, Cardona A. 2012. Fiji: An open-source platform for biological-image analysis. Nature Methods 9:676-682. DOI: 10.1038/nmeth.2019.

Schurr FM, Midgley GF, Rebelo AG, Reeves G, Poschlod P, Higgins SI. 2007. Colonization and persistence ability explain the extent to which plant species fill their potential range. Global Ecology and Biogeography 16:449-459. DOI: 10.1111/j.1466-8238.2006.00293.x.

Scriba M. 2015. Atlas of comparative invertebrate embryology. The Archicoelomata theory. Volume 1. Porifera, Cnidaria, Ctenophora.

Sun Z, Hamel J, Mercier A. 2010. Planulation periodicity, settlement preferences and growth of two deep-sea octocorals from the northwest Atlantic. Marine Ecology Progress Series 410:71-87. DOI: $10.3354 /$ meps08637.

Sun Z, Hamel J-F, Mercier A. 2011. Planulation, larval biology, and early growth of the deep-sea soft corals Gersemia fruticosa and Duva florida (Octocorallia: Alcyonacea). Invertebrate Biology 130:91-99. DOI: 10.1111/j.1744-7410.2011.00229.x.

Taylor ML, Yesson C, Agnew DJ, Mitchell RE, Rogers AD. 2013. Using fisheries by-catch data to predict octocoral habitat suitability around South Georgia. Journal of Biogeography 40:1688-1701. DOI: 10.1111/jbi.12122.

Tempera F, Giacomello E, Mitchell NC, Campos AS, Braga Henriques A, Bashmachnikov I, Martins A, Mendonça A, Morato T, Colaço A, Porteiro FM, Catarino D, Gonçalves J, Pinho MR, Isidro EJ, Santos RS, Menezes G. 2012. Mapping Condor Seamount Seafloor Environment and Associated Biological Assemblages (Azores, NE Atlantic). Seafloor Geomorphology as Benthic Habitat:807-818. DOI: 10.1016/B978-0-12-385140-6.00059-1. 
775

776

777

778

779

780

781

782

783

784

785

786

787

788

789

790

791

792

793

794

795

796

797

798

799

800

801

802

803

804

805

806

807

808

Therneau TM, Grambsch PM. Modeling survival data : extending the Cox model.

Tinevez JY, Perry N, Schindelin J, Hoopes GM, Reynolds GD, Laplantine E, Bednarek SY, Shorte SL, Eliceiri KW. 2017. TrackMate: An open and extensible platform for singleparticle tracking. Methods 115:80-90. DOI: 10.1016/j.ymeth.2016.09.016.

Tong R, Purser A, Unnithan V, Guinan J. 2012. Multivariate statistical analysis of distribution of deep-water gorgonian corals in relation to seabed topography on the Norwegian margin. PLOS ONE 7:e43534. DOI: 10.1371/journal.pone.0043534.

Treml EA, Ford JR, Black KP, Swearer SE. 2015. Identifying the key biophysical drivers, connectivity outcomes, and metapopulation consequences of larval dispersal in the sea. Movement Ecology 3:1-16. DOI: 10.1186/s40462-015-0045-6.

Tyler P, Young C, Clarke A. 2000. Temperature and pressure tolerances of embryos and larvae of the Antarctic sea urchin Sterechinus neumayeri (Echinodermata:Echinoidea):potential for deep-sea invasion from high latitudes. Marine Ecology Progress Series 192:173-180. DOI: 10.3354/meps 192173.

Vermeij MJA. 2009. Floating corallites: A new ecophenotype in scleractinian corals. Coral Reefs 28:987-987. DOI: 10.1007/s00338-009-0535-3.

Watling L, France SC, Pante E, Simpson A. 2011. Biology of Deep-Water Octocorals. DOI: 10.1016/B978-0-12-385529-9.00002-0.

Waller RG, Stone RP, Johnstone J, Mondragon J. 2014. Sexual reproduction and seasonality of the Alaskan red tree coral, Primnoa pacifica. PLoS ONE 9. DOI: 10.1371/journal.pone.0090893.

Weinberg S, Weinberg F. 1979. The life cycle of a gorgonian: Eunicella singularis (Esper, 1794). Bijdragen tot de Dierkunde 48:127-140.

Wells C, Tonra K, Lasker HR. 2020. Embryogenesis, polyembryony and settlement in the gorgonian Plexaura homomalla. bioRxiv.

Wendt DE. 2000. Energetics of larval swimming and metamorphosis in four species of Bugula (Bryozoa). Biological Bulletin 198:346-356. DOI: 10.2307/1542690.

Yesson C, Taylor ML, Tittensor DP, Davies AJ, Guinotte J, Baco A, Black J, Hall-Spencer JM, Rogers AD. 2012. Global habitat suitability of cold-water octocorals. Journal of Biogeography 39:1278-1292. DOI: 10.1111/j.1365-2699.2011.02681.x.

Young CM, He R, Emlet RB, Li Y, Qian H, Arellano SM, Van Gaest A, Bennett KC, Wolf M, Smart TI, Rice ME. 2012. Dispersal of Deep-Sea Larvae from the Intra-American Seas: Simulations of Trajectories using Ocean Models. Integrative and Comparative Biology 52:483-496. DOI: 10.1093/icb/ics090. 
809 Young CM, Devin MG, Jaeckle WB, Ekara Tne SUK, George SB. 1996. OCEANOLOGICA

810

811

812

813

814

815

816

817

818

819 ACTA-VOL. 19-W 3-4 The potential for ontogenetic vertical migration by larvae of bathyal echinoderms Larva Deep-sea Vertical migration Larval nutrition Echinoderm Larve Fond marin Migration verticale Nutrition larvaire Echinoderme ABSTRACT RÉSUMÉ. Gauthier-Villars.

Ben-David-Zaslow R, Benayahu Y. 1998. Competence and longevity in planulae of several species of soft corals. Marine Ecology Progress Series 163:235-243. DOI: $10.3354 /$ meps 163235 .

Zuur AF, Ieno EN, Elphick CS. 2010. A protocol for data exploration to avoid common statistical problems. Methods in Ecology and Evolution 1:3-14. DOI: 10.1111/j.2041210X.2009.00001.x. 


\section{Figure 1}

Stages of embryo development of the octocoral species Dentomuricea aff. meteor

(A) fertilized oocyte. (B) 2-cell. (C) 4-cell. (D) 8-cell. (E) 16-cell. (F) 64-cell. (G) hollow blastula.

(H) gastrula. (I) planula.

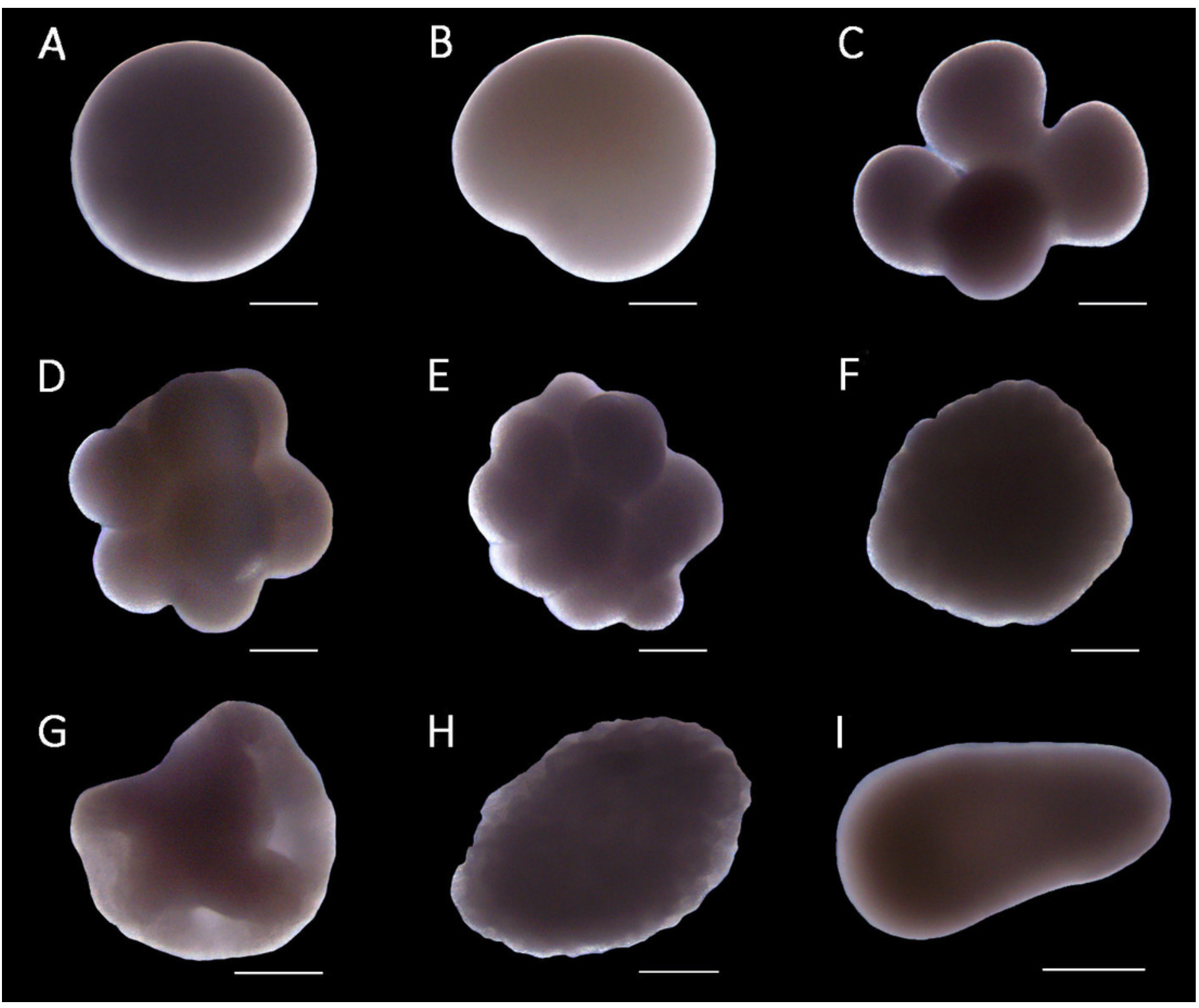


Figure 2

Early development of embryos of the octocoral species Dentomuricea aff. meteor reared under $13^{\circ} \mathrm{C}(\mathrm{A})$ and $15^{\circ} \mathrm{C}(\mathrm{B})$.

Bars display the proportion of embryos in each developmental stage over a course of 96 hours after spawning. Numbers at the base of each bar represent the sample size (n). 


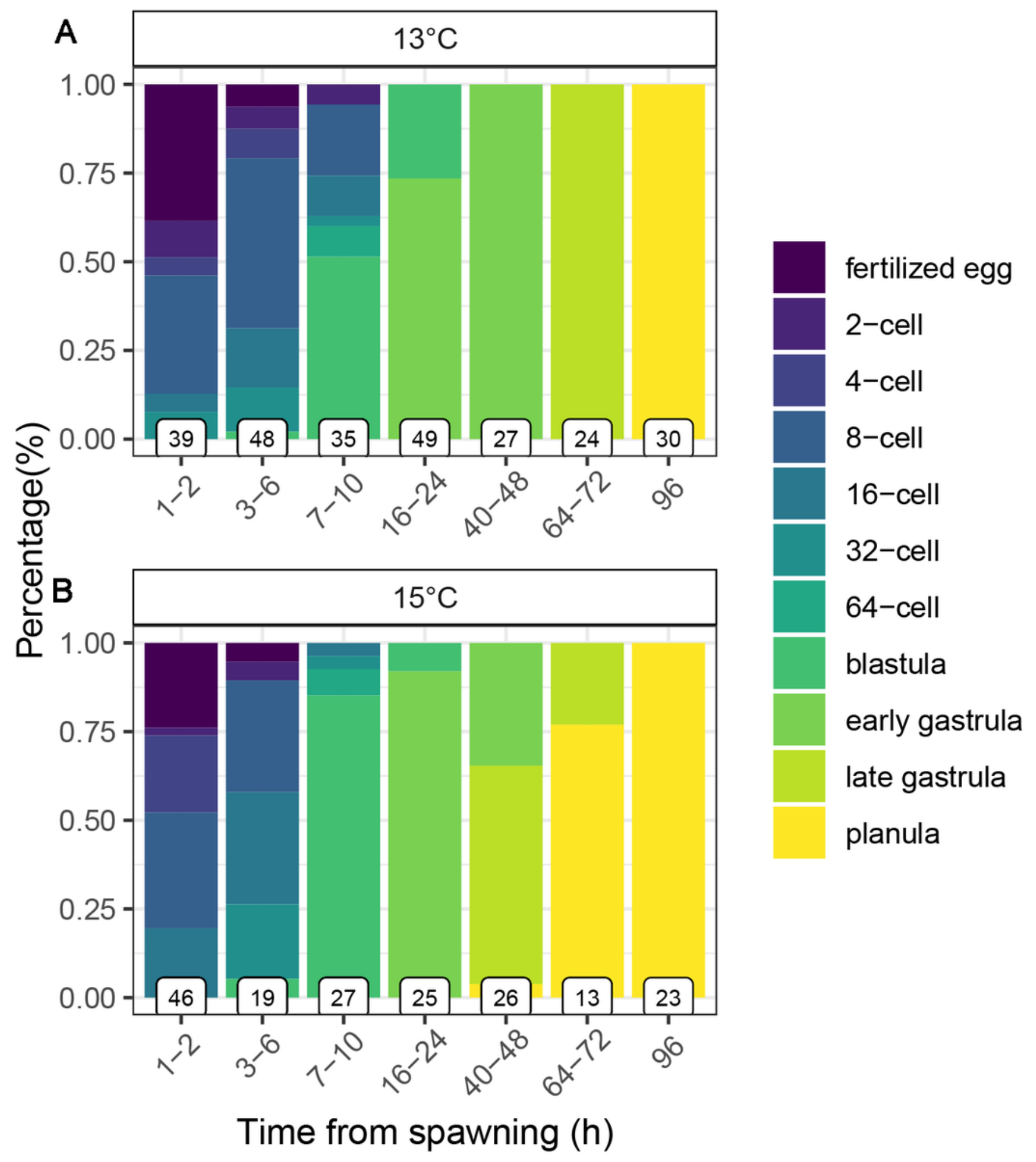


Figure 3

Comparison of Kaplan-Meier estimates of larvae survival of the species Dentomuricea aff. meteor under two temperature regimes.

The initial pool of embryos corresponded to 346 and 342 embryos at $13^{\circ} \mathrm{C}$ and $15^{\circ} \mathrm{C}$, respectively.

Temperature $+13^{\circ} \mathrm{C}+15^{\circ} \mathrm{C}$

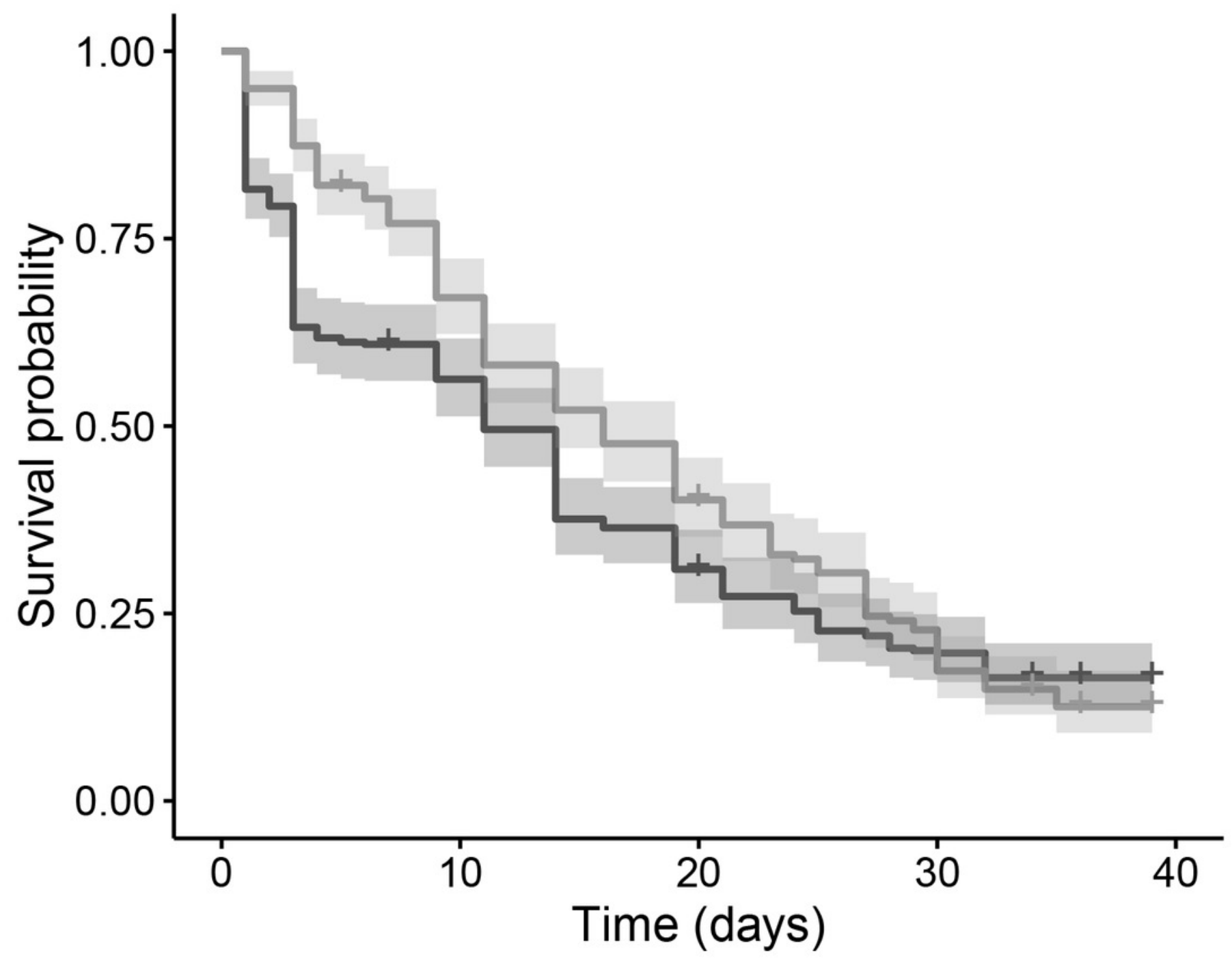




\section{Figure 4}

Larval behaviour of the octocoral species Dentomuricea aff. meteor during the pelagic phase under two experimental rearing temperatures

(A) Total number of surviving larvae in each rearing temperature. (B) Proportion of larvae in different developmental stages (planula, metamorphosed but not settled, settled, deformed) under two experimental rearing temperatures. Dotted vertical line represents the last timepoint when data for all batches were available. 


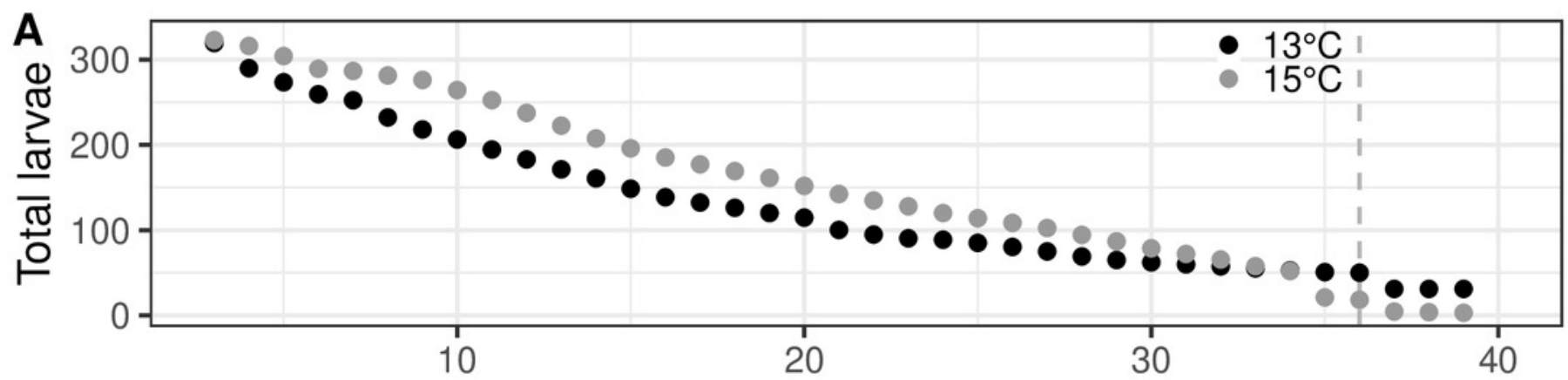

B
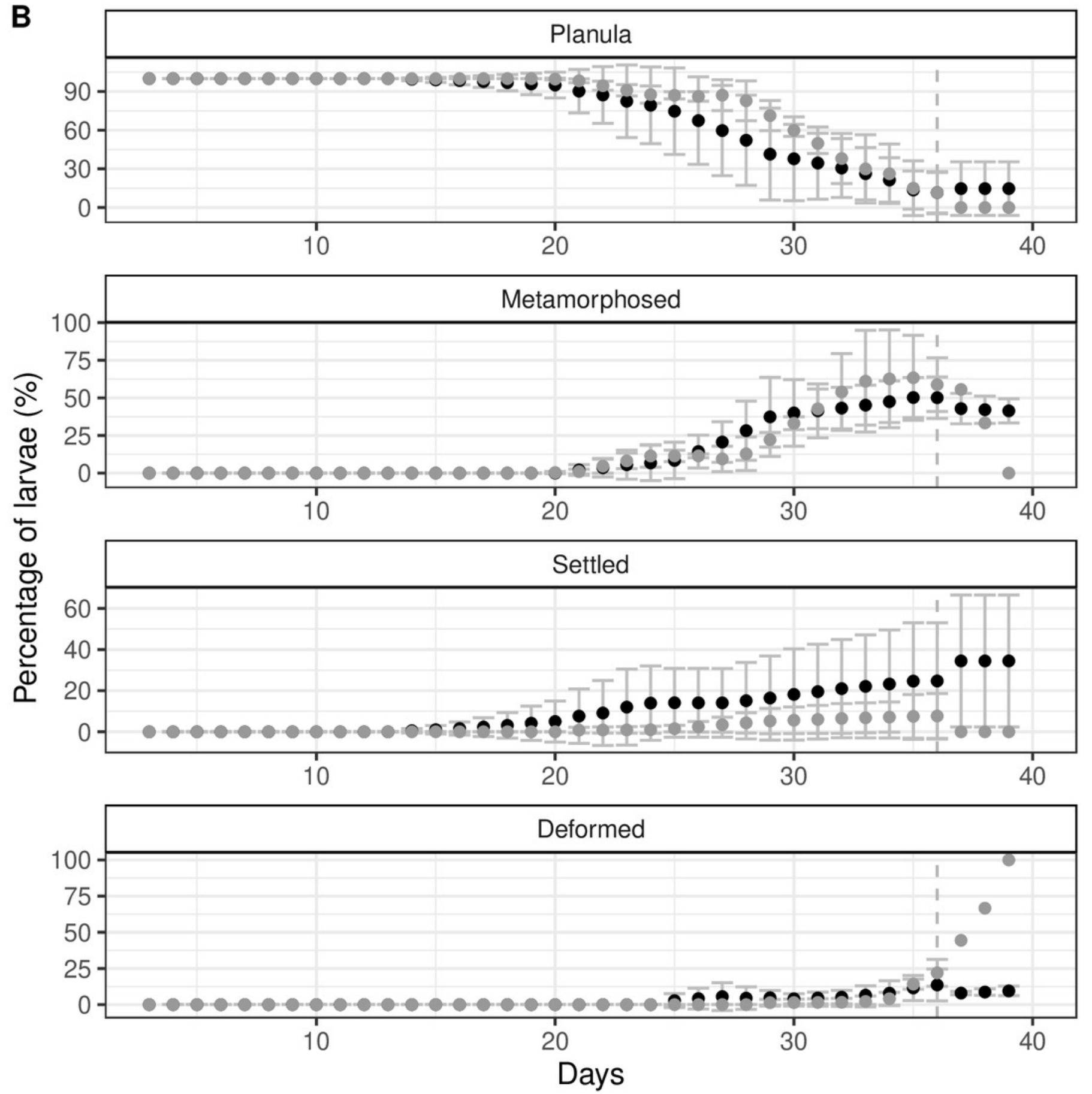


\section{Figure 5}

Formation of primary polyps from planulae of the octocoral Dentomuricea aff. meteor.

(A) Recently settled primary polyp with a polyp base (b) and formation of eight mesenteries $(m)$. (B) Final primary polyp with sclerites $(s)$, tentacles and tentacle pinnules $(p)$. Scale bar: $500 \mu \mathrm{m}$

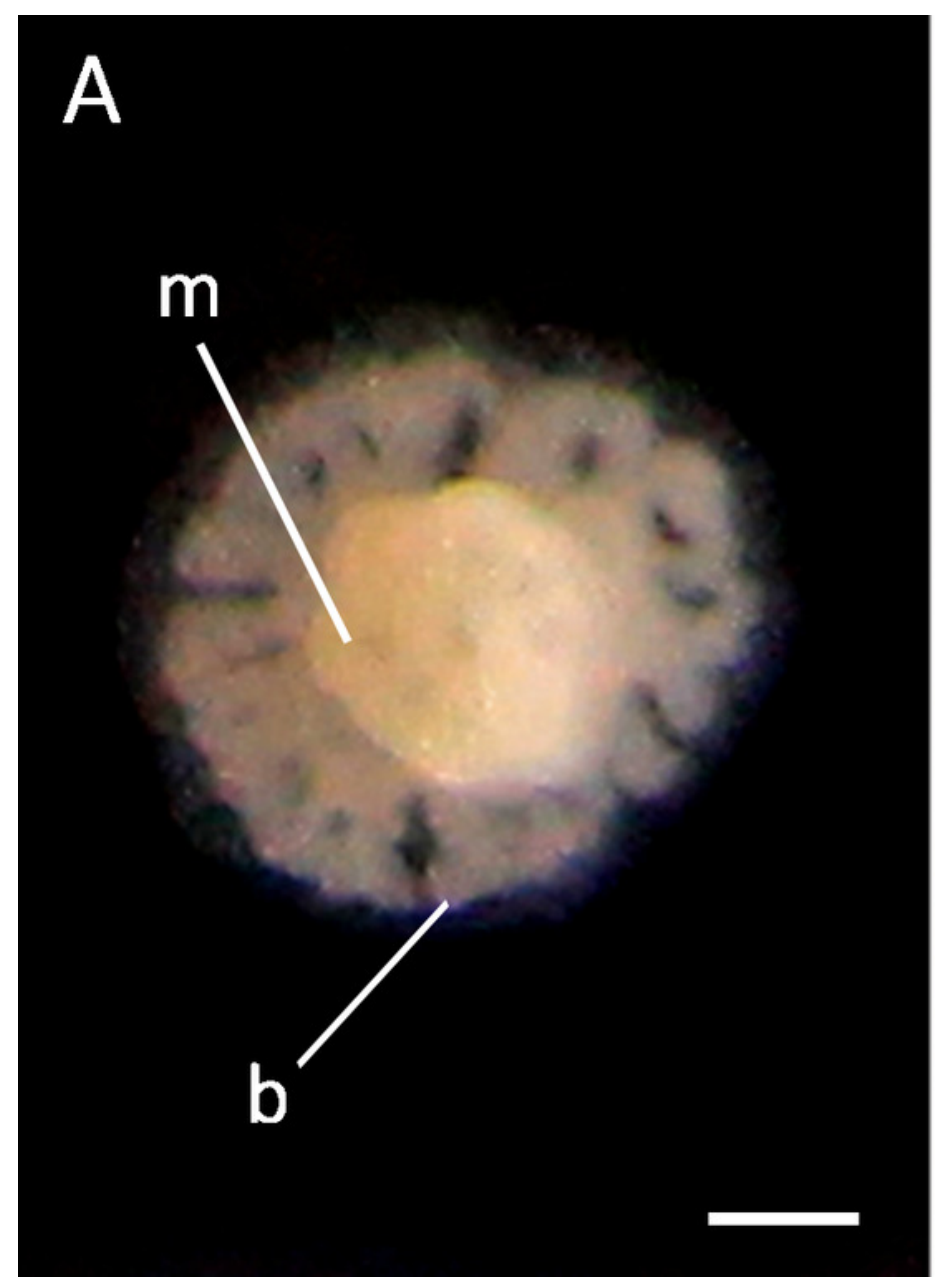

B

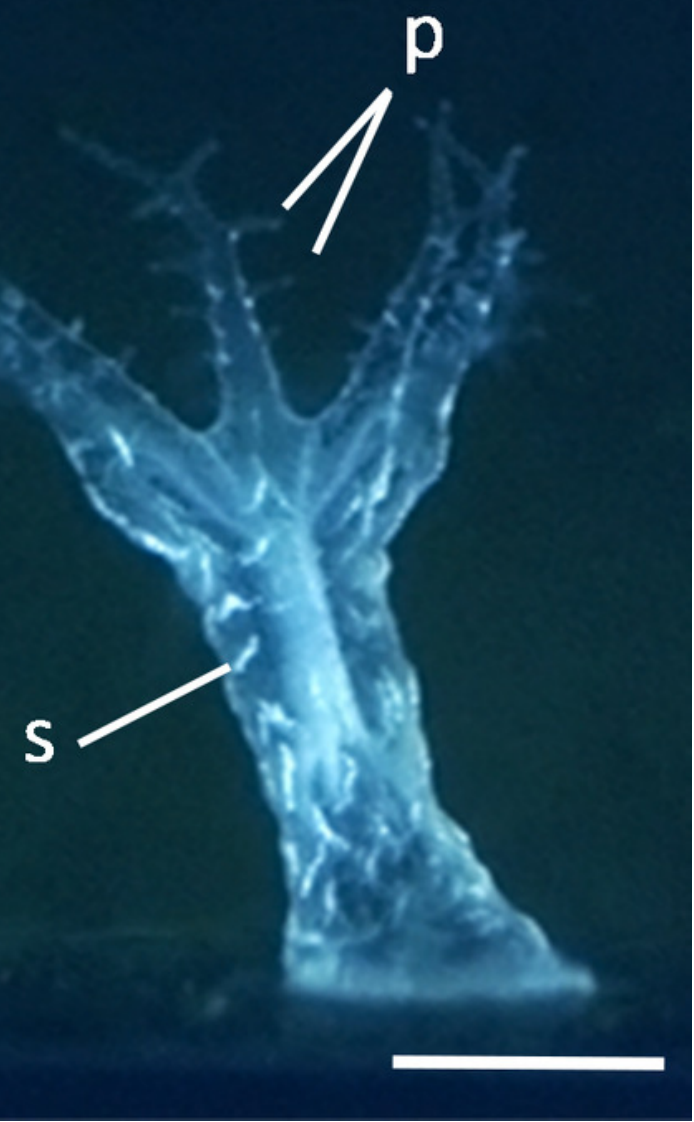




\section{Figure 6}

Pelagic metamorphosis of planulae of the octocoral species Dentomuricea aff. meteor.

(A) pear shaped larva with formed mouth in the oral side (o) and closed aboral side $(a b)$. (B)

Tentacle formation on the oral side. (C) Fully formed tentacles, mesenteries and sclerites (sc). (D) Deformed larva with abnormal mesentery and tentacle formation.
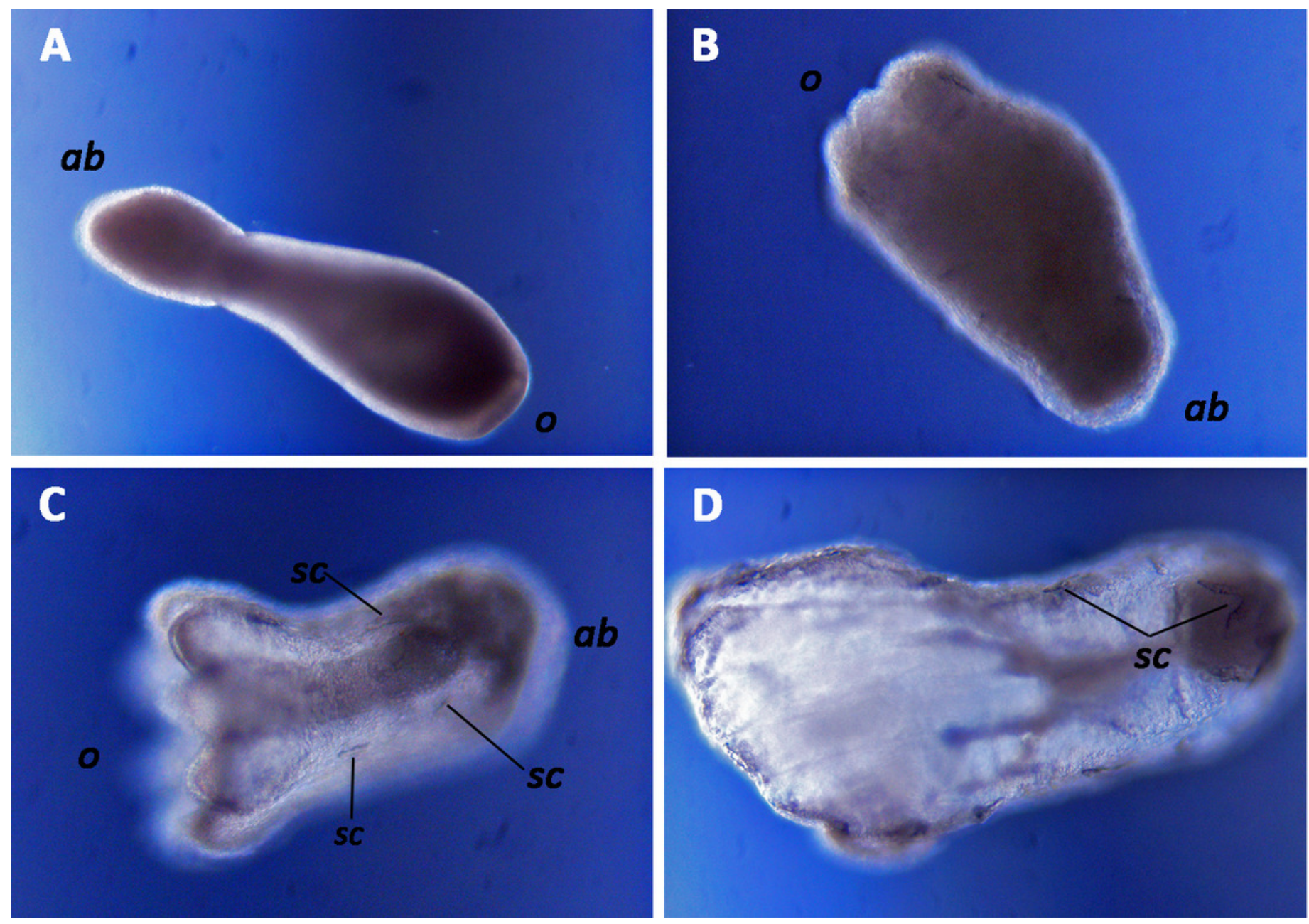


\section{Table $\mathbf{1}$ (on next page)}

Model selection results.

Maximum Likelihood Ratio (MLR) tests reveal significant effects of the independent variables in question. AIC: Akaike Information Criterion, df: degrees of freedom, $p$ : $p$ value of the respective anova test among models. Best models are highlighted in grey. 


\begin{tabular}{|c|c|c|c|c|c|c|}
\hline $\begin{array}{l}\text { Dependent } \\
\text { variable }\end{array}$ & $\begin{array}{l}\text { Model } \\
\text { type }\end{array}$ & Model & AIC & $\mathrm{X}^{2}$ & df & $\mathbf{p}$ \\
\hline \multirow{4}{*}{ Size } & \multirow[t]{4}{*}{ LM } & Null & -186.35 & & & \\
\hline & & Stage & -725.87 & 8.63 & 13 & $\begin{array}{l}2.20 \mathrm{x} \\
10^{-16}\end{array}$ \\
\hline & & $\begin{array}{l}\text { Stage }+ \\
\text { Temperature }\end{array}$ & -724.69 & 0.004 & 12 & 0.37 \\
\hline & & $\begin{array}{l}\text { Stage } \mathrm{x} \\
\text { Temperature }\end{array}$ & -708.56 & 0.03 & 11 & 0.90 \\
\hline \multirow{4}{*}{$\begin{array}{l}\text { Length/width } \\
\text { ratio }\end{array}$} & \multirow[t]{4}{*}{ LM } & Null & 184.68 & & & \\
\hline & & Stage & -132.57 & 21.66 & 13 & $\begin{array}{l}2.20 \mathrm{x} \\
10^{-16}\end{array}$ \\
\hline & & $\begin{array}{l}\text { Stage }+ \\
\text { Temperature }\end{array}$ & -130.58 & 0.0004 & 12 & 0.91 \\
\hline & & $\begin{array}{l}\text { Stage } \mathrm{x} \\
\text { Temperature }\end{array}$ & -159.44 & 1.66 & 11 & $\begin{array}{l}4.78 \mathrm{x} \\
10^{-7}\end{array}$ \\
\hline \multirow{4}{*}{$\begin{array}{l}\text { Swimming } \\
\text { speed }\left(13^{\circ} \mathrm{C}\right)\end{array}$} & \multirow[t]{4}{*}{ LM } & Null & -141.32 & & & \\
\hline & & Time & -170.05 & 1.24 & 1 & $\begin{array}{l}1.95 \mathrm{x} \\
10^{-8}\end{array}$ \\
\hline & & Time + Direction & -168.18 & 0.005 & 1 & 0.71 \\
\hline & & Time $\mathrm{x}$ Direction & -166.18 & 0.00001 & 1 & 0.99 \\
\hline \multirow{4}{*}{$\begin{array}{l}\text { Swimming } \\
\text { speed }\left(15^{\circ} \mathrm{C}\right)\end{array}$} & \multirow[t]{4}{*}{ LM } & Null & 77.12 & & & \\
\hline & & Time & 63.7 & 1.02 & 1 & $\begin{array}{l}7.91 \mathrm{x} \\
10^{-5} \\
\end{array}$ \\
\hline & & Time + Direction & 64.11 & 0.10 & 1 & 0.20 \\
\hline & & Time $\mathrm{x}$ Direction & 65.75 & 0.23 & 1 & 0.54 \\
\hline \multirow{4}{*}{$\begin{array}{l}\text { Swimming } \\
\text { speed }\end{array}$} & \multirow[t]{4}{*}{ LM } & Null & 42.04 & & & \\
\hline & & Time & -24.12 & 4.00 & 1 & $\begin{array}{l}2.20 \mathrm{x} \\
10^{-16} \\
\end{array}$ \\
\hline & & $\begin{array}{l}\text { Time }+ \\
\text { Temperature }\end{array}$ & -79.80 & 3.17 & 1 & $\begin{array}{l}1.41 \mathrm{x} \\
10^{-14}\end{array}$ \\
\hline & & $\begin{array}{l}\text { Time } \mathrm{x} \\
\text { Temperature }\end{array}$ & -77.89 & 0.04 & 1 & 0.767 \\
\hline \multirow{4}{*}{$\begin{array}{l}\text { Swimming } \\
\text { direction } \\
\left(13^{\circ} \mathrm{C}\right)\end{array}$} & \multirow[t]{4}{*}{ LM } & Null & 80.31 & & & \\
\hline & & Time & 82.31 & 0 & 1 & 1 \\
\hline & & Time + Direction & 84.15 & 5.35 & 1 & 0.70 \\
\hline & & Time $\mathrm{x}$ Direction & 82.90 & 95.15 & 1 & 0.11 \\
\hline \multirow{4}{*}{$\begin{array}{l}\text { Swimming } \\
\text { direction } \\
\left(15^{\circ} \mathrm{C}\right)\end{array}$} & \multirow[t]{4}{*}{ LM } & Null & 89.65 & & & \\
\hline & & Time & 91.65 & 0.00 & 1 & 1 \\
\hline & & Time + Direction & 92.38 & 88.60 & 1 & 0.34 \\
\hline & & Time $\mathrm{x}$ Direction & 94.38 & 0.09 & 1 & 0.97 \\
\hline \multirow{3}{*}{$\begin{array}{l}\text { Proportion of } \\
\text { planula }\end{array}$} & \multirow{3}{*}{$\begin{array}{l}\text { Binomial } \\
\text { GAM }\end{array}$} & Null & 4260.04 & & & \\
\hline & & Time & 811.09 & 3454.09 & 2.57 & $\begin{array}{l}2.20 \mathrm{x} \\
10^{-16} \\
\end{array}$ \\
\hline & & Time + & 749.43 & 63.61 & 0.97 & $1.5 \mathrm{x}$ \\
\hline
\end{tabular}




\begin{tabular}{|c|c|c|c|c|c|c|}
\hline & & Temperature & & & & $10-15$ \\
\hline & & $\begin{array}{l}\text { Time } \mathrm{x} \\
\text { Temperature }\end{array}$ & 749.68 & 2.06 & 1.16 & 0.15 \\
\hline \multirow{4}{*}{$\begin{array}{l}\text { Proportion of } \\
\text { metamorphosed }\end{array}$} & \multirow{4}{*}{$\begin{array}{l}\text { Binomial } \\
\text { GAM }\end{array}$} & Null & 2658.9 & & & \\
\hline & & $\mathrm{s}($ Time, $\mathrm{k}=4)$ & 467.12 & 2196.8 & 2.52 & $\begin{array}{l}2.20 \mathrm{x} \\
10^{-16}\end{array}$ \\
\hline & & $\begin{array}{l}\mathrm{s}(\text { Time, } \mathrm{k}=4)+ \\
\text { Temperature }\end{array}$ & 468.32 & 0.80 & 1 & 0.36 \\
\hline & & $\begin{array}{l}\mathrm{s}(\text { Time, } \mathrm{k}=4, \\
\mathrm{by}=\text { Temperature })\end{array}$ & 465.44 & 6.68 & 1.9 & 0.03 \\
\hline \multirow{4}{*}{$\begin{array}{l}\text { Proportion of } \\
\text { settled }\end{array}$} & \multirow{4}{*}{$\begin{array}{l}\text { Binomial } \\
\text { GAM }\end{array}$} & Null & 1359.07 & & & \\
\hline & & $\mathrm{s}($ Time, $\mathrm{k}=4)$ & 670.27 & 694.69 & 2.95 & $\begin{array}{l}2.20 \mathrm{x} \\
10^{-16}\end{array}$ \\
\hline & & $\begin{array}{l}\mathrm{s}(\text { Time }, \mathrm{k}=4)+ \\
\text { Temperature }\end{array}$ & 578.11 & 94.11 & 0.97 & $\begin{array}{l}2.20 \mathrm{x} \\
10^{-16} \\
\end{array}$ \\
\hline & & $\begin{array}{l}\text { s(Time, } k=4, \\
\text { by=Temperature) }\end{array}$ & 564.18 & 17.74 & 1.9 & $\begin{array}{l}1.40 \mathrm{x} \\
10^{-4} \\
\end{array}$ \\
\hline \multirow{4}{*}{$\begin{array}{l}\text { Proportion of } \\
\text { deformed }\end{array}$} & \multirow{4}{*}{$\begin{array}{l}\text { Binomial } \\
\text { GAM }\end{array}$} & Null & 551.37 & & & \\
\hline & & $\mathrm{s}($ Time, $\mathrm{k}=4)$ & 220.45 & 335 & 2.07 & $\begin{array}{l}2.20 \mathrm{x} \\
10^{-16}\end{array}$ \\
\hline & & $\begin{array}{l}\mathrm{s}(\text { Time, } \mathrm{k}=4)+ \\
\text { Temperature }\end{array}$ & 220.05 & 2.44 & 1.02 & 0.11 \\
\hline & & $\begin{array}{l}\mathrm{s}(\text { Time }, \mathrm{k}=4, \\
\mathrm{by}=\text { Temperature })\end{array}$ & 184.87 & 36.86 & 0.84 & $\begin{array}{l}1.26 \times \\
10^{-9} \\
\end{array}$ \\
\hline
\end{tabular}

1 


\section{Table 2 (on next page)}

Summary of embryo and larval characteristics of octocoral species in the order Alcyonacea.

Depth: deep ( $>200 \mathrm{~m})$ and shallow $(<200 \mathrm{~m})$. Reproductive mode: internal brooding (IB), broadcast spawning (BS), surface brooding (SB). T: temperature at which larvae were reared. Larval size is presented as length $(\mathrm{mm})$. Competency refers to the period when larvae are competent to settle. Variables are provided either as range, average \pm standard deviation, maximum (max) or median (median) values. 


\begin{tabular}{|c|c|c|c|c|c|c|c|c|c|c|c|}
\hline Family & Habitat & Depth & $\begin{array}{l}\text { Repr. } \\
\text { mode }\end{array}$ & Species & $\mathbf{T}\left({ }^{\circ} \mathbf{C}\right)$ & $\begin{array}{l}\text { Larval } \\
\text { size } \\
(\mathrm{mm}) \\
\end{array}$ & $\begin{array}{l}\text { Competency } \\
\text { (days) }\end{array}$ & $\begin{array}{l}\text { Longevity } \\
\text { (days) }\end{array}$ & $\begin{array}{l}\text { Swimming } \\
\text { behaviour }\end{array}$ & \begin{tabular}{|l|} 
Swimming \\
speed \\
(cm/s)
\end{tabular} & Reference \\
\hline Alcyoniidae & Temperate & Deep & IB & $\begin{array}{l}\text { Anthomastus } \\
\text { ritteri }\end{array}$ & & $3.3 \pm 1$ & $2-3,123^{\max }$ & & & & Cordes et al., 2001 \\
\hline \multirow[b]{2}{*}{ Coralliidae } & \multirow[b]{2}{*}{ Temperate } & \multirow[b]{2}{*}{ Shallow } & \multirow[b]{2}{*}{ IB } & \multirow[b]{2}{*}{ Corallium rubrum } & 22 & 1.5 & & & & & Weinberg, 1979 \\
\hline & & & & & $19-21$ & 1.0 & & $28.9 \pm 3.3$ & $\begin{array}{l}\text { Vertical } \\
\text { swimming }\end{array}$ & $\begin{array}{l}0.045- \\
0.056\end{array}$ & $\begin{array}{l}\text { Martínez-Quintana } \\
\text { et al., } 2014\end{array}$ \\
\hline \multirow{3}{*}{ Gorgoniidae } & Tropical & Shallow & BS & $\begin{array}{l}\text { Antillogorgia } \\
\text { americana }\end{array}$ & 24 & & $36^{\text {median }}$ & $>60$ & $\begin{array}{l}\text { Vertical } \\
\text { swimming }\end{array}$ & $\begin{array}{l}0.22 \pm \\
0.01^{\max } \\
\end{array}$ & $\begin{array}{l}\text { Coelho and Lasker, } \\
2016\end{array}$ \\
\hline & \multirow[b]{2}{*}{ Temperate } & \multirow[b]{2}{*}{ Shallow } & \multirow[b]{2}{*}{ IB } & \multirow{2}{*}{$\begin{array}{l}\text { Eunicella } \\
\text { singularis }\end{array}$} & 22 & 2.5 & & & & & Weinberg, 1979 \\
\hline & & & & & $18-20$ & & & \begin{tabular}{|l|}
$35.0 \pm$ \\
11.6 \\
\end{tabular} & & & Guizien et al., 2020 \\
\hline \multirow{7}{*}{ Nephtheidae } & Tropical & Shallow & IB & $\begin{array}{l}\text { Parerythropodium } \\
\text { f. Fulvum }\end{array}$ & $21-26$ & & $1-64$ & $76^{\max }$ & & & $\begin{array}{l}\text { Ben-David-Zaslow } \\
\text { and Benayahu, } \\
1998\end{array}$ \\
\hline & Tropical & Shallow & BS & $\begin{array}{l}\text { Dendronephthya } \\
\text { hemprichi }\end{array}$ & $21-26$ & & $2-74$ & $81^{\max }$ & & & $\begin{array}{l}\text { Ben-David-Zaslow } \\
\text { and Benayahu, } \\
1998\end{array}$ \\
\hline & Tropical & Shallow & IB & $\begin{array}{l}\text { Litophyton } \\
\text { arboreum }\end{array}$ & $21-26$ & & $1-57$ & $92^{\max }$ & & & $\begin{array}{l}\text { Ben-David-Zaslow } \\
\text { and Benayahu, } \\
1998\end{array}$ \\
\hline & Tropical & Shallow & IB & Nephthea sp. & $21-26$ & & $1-57$ & & & & $\begin{array}{l}\text { Ben-David-Zaslow } \\
\text { and Benayahu, } \\
1998\end{array}$ \\
\hline & Subarctic & Deep & IB & $\begin{array}{l}\text { Gersemia } \\
\text { fruticosa }\end{array}$ & & $1.5-2.5$ & $40-70$ & & Swimming & & Sun et al., 2011 \\
\hline & Subarctic & Deep & IB & Duva florida & $0-9$ & $1.0-2.5$ & 5 & & Crawling & & Sun et al., 2011 \\
\hline & Subarctic & Deep & IB & Drifa glomerata & 2 & $4.0-5.0$ & & & & & Sun et al., 2010 \\
\hline \multirow{2}{*}{ Plexauridae } & Tropical & Shallow & BS & Plexaura kuna & $28-30$ & 2.0 & $4-21$ & & & & $\begin{array}{l}\text { Lasker and Kim, } \\
1996\end{array}$ \\
\hline & Temperate & Shallow & SB & $\begin{array}{l}\text { Paramuricea } \\
\text { clavata }\end{array}$ & $18-20$ & & & $32 \pm 11$ & Crawling & & Guizien et al., 2020 \\
\hline
\end{tabular}




\begin{tabular}{|c|c|c|c|c|c|c|c|c|c|c|c|}
\hline & Tropical & Shallow & BS & $\begin{array}{l}\text { Plexaura } \\
\text { homomalla }\end{array}$ & $27-29$ & 1.0 & 4 & & $\begin{array}{l}\text { Swimming } \\
\text { and } \\
\text { crawling }\end{array}$ & 0.5 & Wells et al., 2020 \\
\hline & \multirow{2}{*}{ Temperate } & \multirow{2}{*}{ Deep } & \multirow{2}{*}{$\mathrm{BS}$} & \multirow{2}{*}{$\begin{array}{l}\text { Dentomuricea aff. } \\
\text { meteor }\end{array}$} & 13 & $\begin{array}{l}1.15 \pm \\
0.28\end{array}$ & 25 & 11 & $\begin{array}{l}\text { Swimming } \\
\text { and } \\
\text { crawling }\end{array}$ & $\begin{array}{l}0.024- \\
0.036\end{array}$ & This study \\
\hline & & & & & 15 & $\begin{array}{l}1.14 \pm \\
0.28\end{array}$ & 29 & 16 & $\begin{array}{l}\text { Swimming } \\
\text { and } \\
\text { crawling }\end{array}$ & $0.04-0.044$ & This study \\
\hline \multirow{2}{*}{ Xeniidae } & Tropical & Shallow & IB & Xenia umbellata & $21-26$ & & $2-76$ & $155^{\max }$ & & & $\begin{array}{l}\text { Ben-David-Zaslow } \\
\text { and Benayahu, } \\
1998\end{array}$ \\
\hline & Tropical & Shallow & IB & $\begin{array}{l}\text { Heteroxenia } \\
\text { tuscescens }\end{array}$ & $21-26$ & & $49 \max$ & $50^{\max }$ & & & $\begin{array}{l}\text { Ben-David-Zaslow } \\
\text { and Benayahu, } \\
1998\end{array}$ \\
\hline
\end{tabular}

